\title{
Review on the methodology used in thermal stability characterization of phase change materials
}

\author{
Gerard Ferrer $^{1}$, Aran Solé ${ }^{1}$, Camila Barreneche ${ }^{1,2}$, Ingrid Martorell ${ }^{1,3}$, Luisa F. Cabeza ${ }^{1}$ \\ ${ }^{1}$ GREA Innovació Concurrent, Edifici CREA, Universitat de Lleida, Pere de Cabrera s/n, 25001, Lleida, Spain, Phone: +34-973- \\ 003576, Fax: 34-973-003575, e-mail: lcabeza@diei.udl.cat \\ ${ }^{2}$ Department of Materials Science \& Metallurgical Engineering, Universitat de Barcelona, MartíiFranqués 1-11, 08028, Barcelona, \\ Spain. Tel: +34-934021298. e-mail: cbarreneche@ub.edu \\ ${ }^{3}$ Serra-Hunter fellow
}

\begin{abstract}
In general, PCM are classified in organic and inorganic groups or families. First group mainly encloses paraffin, fatty acids, and sugar alcohols. Inorganic are mostly represented by salt hydrates, salt solutions, and metals. Eutectics and mixtures are also being formulated to obtain a desired phase change temperature. One of the most important PCM requirements is being stable after a number of repeated melting/freezing cycles, which is known as cycling stability. A PCM should present the same or almost the same thermal, chemical and physical properties after a repeated number of freezing and melting cycles. Thermal cycling tests results and detailed tests procedures are classified by PCM type in this review. Moreover, the parameters that must be considered in order to perform cycling stability tests are highlighted depending on the importance they have on the following four issues: the choice of the equipment to perform the cycling tests; the selection of the techniques to characterize the PCM before and after thermal cycling test and to follow the PCM thermal degradation; the definition of the number of cycles to perform; and finally, the choice of the heating rate and thermal cycling method (pyramid, or dynamic, or others) to perform the tests. It is mandatory to conclude that, based on the literature reviewed, no common standard for thermal cycling stability tests is available at the moment.
\end{abstract}

Keywords: phase change materials (PCM), cycling stability, thermal stability, differential scanning calorimetry (DSC), thermal cycler, thermal energy storage (TES) 


\section{Introduction}

Current trends in energy supply and use are patently unsustainable - economically, environmentally and socially [1]. Energy policies are focusing on achieving net zero buildings and on reusing waste heat from the industry. Then, fossil fuel and electricity consumption can be decreased and consequently, $\mathrm{CO}_{2}$ emissions too. Furthermore, the use of renewable energies is pushing to design new technologies implementing them as a primary source. One huge field implementing waste heat utilization and solar energy is thermal energy storage (TES).

One way of storing heat is by using the latent heat of phase change of a substance, usually from solid to liquid, as it can provide high energy densities. Then, when this stored heat is needed, it can be released by leaving the material temperature decrease, becoming a solid again. Materials used for this purpose are known as phase change materials (PCM). PCM are being implemented in different systems, active or passive, and for several applications, cold storage, building comfort, medium and high temperatures [1-5].

In general, PCM are classified in organic and inorganic. First group mainly encloses paraffin, fatty acids, and sugar alcohols. Inorganic are mostly represented by salt hydrates, salt solutions, and metals $[3,6]$. Eutectics and mixtures are also being formulated to obtain a desired phase change temperature. All these materials present advantages and disadvantages, as exposed in Table 1.

Moreover, to overcome some of these disadvantages, composites, shape-stabilized or formstable PCM are being formulated and developed. Composites are mainly thought to enhance thermal conductivity, increase cycling stability, and prevent leakage and corrosion [7-10]. In addition, the combination of nucleating agents with PCM is presented as a solution to decrease subcooling.

The main requirements from the material point of view are, of course, high phase change enthalpy and a suitable phase change temperature, depending on the application in which the PCM needs to be implemented. Furthermore, a PCM is suitable for applications if it is stable after a number of repeated melting/freezing cycles, that is to say, if it has a proper cycling stability. Sometimes it is also called long term stability [5]. This stability encloses thermal, chemical and physical properties, which should remain constant or almost constant after a cycling stability test. Chemical stability is usually studied by infrared spectroscopy (FT-IR) [11]. Another concept is thermal stability. A thermal stability test is useful to ensure that the 
PCM is stable at a constant established working temperature. The maximum temperature the PCM can stand is known as the degradation temperature. Thermal stability can be studied in an oven or with TGA [4]. The present review is focused on the thermal cycling stability.

Table 2 reviews the importance given to thermal cycling stability as mentions in different published articles. As shown, and despite the relevance given to these parameters, not much data is available in these publications.

Up to now, few reviews found in the literature highlight the importance of thermal cycling stability, but they do not look at the methodology nor the equipment used in such analysis. Data discrepancy suggests that this property is still not assessed in depth. Moreover, some reviews present only differential scanning calorimeter (DSC) as the analytical equipment, but although DSC is used by all researchers to analyse the materials, it is not always used for cycling them.

Therefore, this paper presents a review on the thermal cycling stability data of PCM found in the literature, but focusing on the methodologies used by the different researchers, along with the equipment used and the analytical conditions in which the tests were carried out in order to find out the existence of a common and useful methodology to develop these tests.

\section{Thermal cycling stability testing of PCM}

As detailed in the introduction, cycling stability is one key property of PCM to be studied since their lifetime depends on it. A PCM should present the same or almost the same thermal, chemical and physical properties after a repeated number of freezing and melting cycles. Here, thermal cycling tests results and detailed tests procedures are reviewed and shown by PCM type.

It is important to point out that authors just present the results of each consulted study, but do not seek for any phenomena explanation as it is clearly explained in each one of the cited papers. As it is already stated in the introduction, the goal of the present paper is to compile information published in order to find out if there is a common pattern to study the thermal stability of PCM or there is not. 


\subsection{Paraffin}

Table 3 shows the results of the cycling of several paraffin waxes found in the literature. Analytical conditions are first presented, not only the melting properties but also crystallization ones, along with the number of thermal cycles performed. Then, the equipment used for both cycling and properties analysis tests are listed as well as the analysis method used.

Only nine materials are found in this list. The cycled paraffin reported in the literature are both analytical grade and commercial grade, and their melting points range from around $18{ }^{\circ} \mathrm{C}$ to 58 ${ }^{\circ} \mathrm{C}$; the numbers of cycles carried out were between 300 and 5000 .

All authors show the melting point and the latent heat of fusion before and after the thermal cycling process. Three of the studies, the one performed by Alkan et al. [30], the investigation by Sari et al. [31], both from the same research group at Gaziosmanpaşa University in Turkey, and the research by Silakhori et al. [62], also present information about the latent heat of crystallization. The melting point is taken as the onset temperature on the DSC curve and the latent heat of fusion is calculated using the area under the peak in all cases but the two microencapsulated paraffin studied by Silakhori et al. [62], who do not report the calculating method.

Four different DSC instruments and analysis methods were used in the different investigations to study the thermal properties of the paraffin. Alkan et al. [30] used a Setaram 131 DSC, fixing a heating rate of $5^{\circ} \mathrm{C} / \mathrm{min}$ under a constant stream of argon at a flow rate of $60 \mathrm{ml} / \mathrm{min}$ (inert atmosphere). Sari et al. [31] used the same operating mode in a Perkin Elmer Diamond DSC. Sharma et al. [26,27] used a Rheometric Scientific Ltd. DSC following a dynamic method. Shukla et al. [29] also used a Rheometric Scientific Ltd. DSC but no specification on the followed operating mode was exposed. However, none of them used the DSC to perform the cycling tests of the samples. Alkan et al. [30] and Sari et al. [31] used a thermal bath setup to melt and solidify the samples by water circulation, while Sharma et al. [26,27] performed the melting-freezing processes using an electric hot plate setup, letting the samples solidify at room temperature. Shukla et al. [29] cycled the samples using an oven and let the paraffin solidify at room temperature as well. Silakhori et al. [62] cycled the PCM in a thermal box equipped with a strip heater and a deep cooler and measured the thermal properties in a Mettler Toledo 820C DSC.

Paraffin wax 53 is the only material presented in Table 3 that has been studied in more than one paper and can lead to some results comparison. The two different studies that Sharma et al. 
[26,27] did under the same experimental conditions clearly show that the PCM loses heat storage capacity when cycled. This loss is quantified by the decrease the latent heat of fusion experienced after 1500 cycles, which is around $26 \%$, considerably higher than the $10 \%$ suffered after 300 cycles. The melting temperature also showed a $3{ }^{\circ} \mathrm{C}$ decrease after 1500 cycles, a remarkable fact compared to the null variation the PCM's melting point suffered after 300 cycles. Both studies also present the data logged during the cycling process to see the profile the latent heat loss follows and in both cases this loss happens around the mid experimental point, after 100 and 700 cycles, respectively.

\subsection{Non-paraffin non-eutectic organic materials}

Table 4 presents the results of fifteen non-paraffin non-eutectic organic materials cycled in the literature. These materials include amides, fatty acids, sugar alcohols, and other materials such as urea. Their melting temperatures range from $19{ }^{\circ} \mathrm{C}$ to $216^{\circ} \mathrm{C}$, and they have been cycled between 50 and 5000 times.

As an overview of the data presented in Table 4, all authors except studies [39] and [36] presented both melting temperature and latent heat of fusion before and after the cycling process. Nikolic et al. [39] only showed the data taken before cycling and oppositely, Abhat and Malatidis [36] only presented the data collected after cycling the samples. Moreover, just four authors out of twelve (33\%) also give information about the latent heat of crystallization before and after the cycling process.

Regarding the thermal parameters calculation, the melting point was taken as the onset temperature on the DSC curve and the latent heat of fusion was calculated using the area under the peak in all the studies but the one done by Solé et al [11], where the melting temperature was taken as the peak temperature on the DSC curve, calculating the latent heat with the area under the peak as well. Abhat and Malatidis [36] do not enclose information about the parameters calculations.

Eight different DSC instruments were used in all these different studies but only half of them were also used to cycle the samples. Only acetamide, lauric acid, myristic acid, palmitic acid and stearic acid have been studied by more than one author, thus it is only possible to compare the results regarding these four materials.

Sharma et al. $[26,27]$ studied acetamide as a potential heat storage material. In study [26] the samples were cycled 300 times and in [27] the cycling process was repeated 1500 times. A 
Rheometric Scientific Ltd. DSC was used in both studies to find out acetamide thermal properties, following the same DSC method and using a hot plate setup to cycle the samples in both cases. Results show a more important loss on heat storage capacity after 300 cycles $(8.4 \%)$ than after 1500 cycles (1.2\%), as the obtained latent heat values show. In addition, data in some mid points of the cycle process was also attached to see the evolution that each parameter has with its thermal cycling stability. In both studies, the melting temperature remains quite constant during all the cycling process and the latent heat values do not seem to follow any clear pattern as they increase and decrease randomly with the number of cycles.

Sari [33] (1200 cycles) and Sari and Kaygusuz [40] (910 cycles) studied the thermal properties of lauric acid for its application as PCM. Their studies were done under the same experimental conditions: in both of them a General V4.1C DuPont 2000 DSC was used, following the same $10{ }^{\circ} \mathrm{C} / \mathrm{min}$ heating rate in the analysis method and using a thermostatic chamber setup for the cycling process of the samples. The results displayed in Table 4 show differences between the initial and final latent heat values of both studies despite being done with the same equipment and procedures. The authors also presented some midpoint data about the thermal properties during the experiment, which show a substantial difference on the evolution the latent heat experiences with the cycle time: in Sari and Kaygusuz [40] the latent heat values exponentially decrease with the number of cycles whereas in Sari [33] they do not have a clear pattern as values first decrease but after 600 cycles increase again. Abhat and Malutidis [36] cycled 3 times the lauric acid samples in a Perkin Elmer DSC 2. The only reported data are the latent heat of fusion, the latent heat of crystallization and the melting point after the 3 cycles, but not before the cycling process. No information about the DSC method used is reported in the paper, and the parameter calculation considerations are neither explained, therefore no conclusions about the methodology followed by them can be withdrawn

Myristic acid was studied by Hasan and Sayigh [37], Sari [33], and Sari and Kaygusuz [40]. Studies [33] and [40] used the same setup for the experimental process: a General V4.1C DuPont 2000 DSC, with a heating rate of $10^{\circ} \mathrm{C} / \mathrm{min}$, and a thermostatic chamber setup to cycle the samples. However, results differ a bit and no clear pattern is observed as more energy storage capacity is lost (18\%) in study [40] after 910, than in study [33], where the samples were cycled 1200 times and the losses were around 12\%. In addition, the midpoint data enclosed in both articles show significant differences on the way the latent heat of fusion decreases with time, as in Sari's [33] it drops a lot before it increases again and in [40] the decrease is mostly constant with the number of cycles. On the other hand, Hasan and Sayigh [37] performed the tests in a Perkin Elmer DSC 2, setting the heating rate to analyse the thermal properties on $10{ }^{\circ} \mathrm{C} / \mathrm{min}$ and cycling the samples with a two thermostatic bath setup. Results 
showed a $14 \%$ loss in energy storage capacity, keeping a quite constant melting point that, however, was a bit lower than the melting temperatures experienced in the other two studies.

The same three authors studied palmitic acid with the same experimental setups used in the myristic acid respective studies. Again, studies [33] and [40], done under the same experimental conditions, show higher energy storage capacity loss in the 910 cycles study, 18\%, than in the 1200 times cycled study, which is around $13 \%$. They differ on the final latent heat value obtained, lower in study [40], and the diminution tendency experienced by the latent heat. Hasan and Sayigh [37] obtained a lower energy storage capacity loss, 9\%, and higher latent heat values cycling the samples 450 times. Abhat and Malutidis [36] also studied this fatty acid. The palmitic acid samples were cycled 5 times in a Perkin Elmer DSC 2 and they enclosed data of the latent heat of fusion, the latent heat of crystallization and the melting point after those 3 cycles, but not before the cycling process. No information about the DSC analysis method neither the parameters calculation is reported in the paper.

Five different authors studied stearic acid thermal properties. Sharma et al. [26] performed their experiments using a Rheometric Scientific Ltd. DSC following a dynamic method and cycling the samples 300 times in an electric hot plate setup. The displayed results show constant melting temperature and a low increase of the latent heat of fusion. These results contrast with the ones obtained under the same experimental conditions in Sharma's later study [27], where the samples where cycled 1500 times and a $21 \%$ energy storage capacity loss was experienced by the material. Hasan and Sayigh [37] obtained the highest melting point and latent heat values for stearic acid of all the referenced studies. They cycled the samples using a two thermostatic bath setup and the thermal properties determination was carried out in a Perkin Elmer DSC 2 under a $10{ }^{\circ} \mathrm{C} / \mathrm{min}$ heating rate. After 450 cycles the melting temperature remained quite constant but the latent heat of fusion decreased $12 \%$, from $209.9 \mathrm{~J} / \mathrm{g}$ to $185.3 \mathrm{~J} / \mathrm{g}$. The authors also enclosed a table with one mid experimental point after 101 cycles which shows a low decrease on the latent heat value during the first 100 cycles followed by a greater heat storage capacity loss until the final experimental point. The two stearic acid studies that cycled the samples more times were the ones performed by Sari [33] and Sari and Kaygusuz [40]. Both investigations were done under the same experimental conditions, using a thermostatic chamber to cycle the samples and a General V4.1C DuPont 2000 DSC to analyze the thermal properties under a constant heating rate of $10{ }^{\circ} \mathrm{C} / \mathrm{min}$. Results show substantial differences on the latent heat values obtained, as in study [33], after 1200 cycles, the latent heat loss was lower than $2 \mathrm{~J} / \mathrm{g}$ while in study [40] a $32 \%$ loss in the heat storage capacity was experienced after 910 cycles. In both cases some mid experimental point data is attached and the patterns followed by the latent heat of fusion are really different as well: in study [40] latent heat decreases during all the experiment while in 
study [33] it experiences random increases and decreases during the 1200 cycles. Regarding the melting temperatures, they were quite similar between these two studies. However, both initial and final melting temperatures were considerably lower $(15 \%)$ than in the other three investigations.

Solé et al. [11] studied the thermal properties of d-mannitol, myo-inositol and galacticol using a Q200 TA Intruments DSC for both cycling and thermal properties measurement. They took the melting temperature as the peak temperature on the DSC curve. The enthalpies were calculated using the area under the peak. They present one mid experimental point for every sugar alcohol study.

\subsection{Organic eutectics}

The thermal properties of twenty one organic eutectics cycled in thirteen papers of the cited literature are shown in Table 5. Most materials are mixtures of fatty acids, with a few exceptions. The melting points of the eutectics vary from $13{ }^{\circ} \mathrm{C}$ to $64{ }^{\circ} \mathrm{C}$ and the number of cycles ranges from 100 up to 5000 .

Just four out of the thirteen different authors present information about the latent heat of fusion and the melting point before and after the cycling tests, and the same papers are the only ones that also show information about the latent heat of crystallization.

$50 \%$ of the authors do not explain how the melting point and the latent heat of fusion were measured. The others took the phase change temperature as the onset temperature obtained by drawing a line at the point of maximum slope of the leading edge of the DSC peak and extrapolating baseline on the same side as the leading edge of the peak. The latent heat of the phase change was calculated by integration of the area under the peak of the DSC curve.

Ten different DSC instruments were used to obtain the thermal data of these organic eutectics, but only Zhang et al. [32] and Nikolic et al. [39] also used the DSC to cycle the samples. The other studies performed the cycling tests using different equipment and setup configurations.

The eutectic capric acid $(65 \mathrm{~mol} \%)+$ lauric acid $(35 \mathrm{~mol} \%)$ is the only one studied by two different authors. Dimaano and Escoto [50] cycled the eutectic samples 120 times in a thermostatic water bath setup and used a Mettler TA 4000 DSC to measure the thermal properties, while Shilei et al. [53] used an electric hot plate setup to cycle 360 times the samples and a non-specified DSC to determine the thermal properties. Both authors only presented the 
measures before cycling the samples, and results show that in Shilei et al. [53] the obtained latent heat of fusion was $8 \%$ higher than the one obtained by Dimaano and Escoto [50]. The same tendency is observed when comparing the melting points obtained in both studies, as Shilei et al. [53] obtained a $6{ }^{\circ} \mathrm{C}$ higher melting point than Dimaano and Escoto [50] did in their study. So, there already is an important difference on both parameters values even before the cycling stability study.

\subsection{Salt hydrates}

Cycling of seven salt hydrates has been reported in the literature. The melting temperature of these materials ranges from $8.5^{\circ} \mathrm{C}$ to $111^{\circ} \mathrm{C}$, and as 
Table 6 shows, they have been cycled from 100 to 5650 times.

$70 \%$ of the authors did not provide data of the final melting point and the latent heat of fusion. Only Fellchenfeld et al. [44] gave information about the latent heat of crystallization and just the $50 \%$ of the authors reported how the melting point and the latent heat of fusion were calculated. Indeed, the same methodology was followed by all these $50 \%$ more descriptive researchers: the latent heat of fusion was calculated using the area under the peak of the DSC curve, and the melting point was taken as the onset temperature on the same DSC curve.

$90 \%$ of all the presented studies concerning salt hydrates used a DSC to measure the thermal properties of the different salts. Six different setups were used in these studies to cycle the samples. Porosini [45] was the only author that did not use a DSC in any part of the experimentation as its investigation goal was not to study the heat storage capacity of these salts but to describe the effect of thermal cycling on the PCM physical state.

Five different authors studied calcium chloride hexahydrate heat storage capacity and gave results on its cyclability. Tyagi et al. [48] used a TA Instruments DSC Q-100 to measure the salt's thermal properties and were the only ones that presented information of the melting point and the latent heat of fusion before and after the cycling experiment. Furthermore, they also performed the sample cycling in the DSC. After 1000 cycles, results show constant values for both melting point and latent heat of fusion, hence no heat storage capacity was lost according to them. In addition, the authors also presented mid experimental points to study the pattern that both parameters followed during the whole study, but no clear tendency was seen in neither of the cases; random increases and decreases were experienced by both melting point and latent heat of fusion. Kimura and Kai [60] and Fellchenfeld et al. [44] also cycled 1000 times calcium chloride hexahydrate samples but the results obtained were substantially different from the ones already explained above. Kimura and Kai [60] performed the analysis in a Perkin Elmer DSC 2 but they cycled the salt in a two tube setup with water circulation. The obtained melting point was $6^{\circ} \mathrm{C}$ higher than the achieved in Tyagi et al. [48], and the latent heat of fusion was of 190 $\mathrm{J} / \mathrm{g}$, which is $35 \%$ more heat storage capacity than Tyagi et al. [48] results. Fellchenfeld et al. [44] measured the thermal properties of the PCM in a Mettler DSC but they performed the cycling using a water bath setup, obtaining the lowest latent heat of fusion of the analyzed studies, $86 \mathrm{~J} / \mathrm{g}$, and a melting point of $28{ }^{\circ} \mathrm{C}$. They also gave the latent heat of crystallization value, which again was really poor, $71 \mathrm{~J} / \mathrm{g}$. Porosini [45] did also perform experiments with this salt, however, the study was not focused on determining the heat storage capacity of the salt, hence only information about the initial melting point and the number of cycles is given along with some description of the PCM physical state. Abhat and Malatidis [36] also experimented 
with this salt, again with a Perkin Elmer DSC 2, but only information about the melting point and the latent heat of fusion after the 18 performed cycles is enclosed in their publication. No method explanation is given by the authors in [36] as well as no specifications on how the parameters were calculated are found in the paper. However, they undertook the experimentation in two different operation modes: with hermetically sealed pans and with nonhermetically sealed or "open" pans. Results show that the salt undergoes decomposition in the tests with open pans, so their recommendation is to use this salt hydrate only in hermetically sealed storage systems.

Glauber's salt was studied by Marks [59] and Porosini [45]. Despite the analysis methods and the cycling time being different, the same initial melting point was found in both studies. However, the study by Porosini [45] was not focused on determining the heat storage capacity of the salt, hence, no other information but the cycling time and melting point was given in the paper. On the other hand, Marks [59] measured the initial latent heat of fusion and melting point using a calorimeter and cycled the samples in a thermal cycling chamber. The initial melting point and latent heat of fusion results are enclosed in the former Table 5 and the only information reported in the paper after 200 cycles is the latent heat of fusion that decreased until $105 \mathrm{~J} / \mathrm{g}$, losing a $56 \%$ of its storage capacity.

El-Sebaii et al. [42,58] did two studies of the magnesium chloride hexahydrate thermal properties after 500 and 1002 cycles, respectively. Both studies used the same equipment and methods: a Heraeus D-6450 Electric Oven was used to cycle the samples and Shimadzu DSC60 to analyze the thermal properties. In the DSC, the samples were heated at a constant rate of $10{ }^{\circ} \mathrm{C} / \mathrm{min}$ between room temperature and $200{ }^{\circ} \mathrm{C}$ and under a constant nitrogen stream. Substantial differences on both initial and final values can be observed, as after 1002 cycles only $6 \%$ of the heat storage capacity is lost, while study [42] presented a $46 \%$ loss as the latent heat of fusion dropped from $155.11 \mathrm{~J} / \mathrm{g}$ to $85 \mathrm{~J} / \mathrm{g}$ in half of the time. In addition, the initial latent heat values of both studies differed $17^{\circ} \mathrm{C}$. Both measured melting points experienced an important increase with the number of cycles, more remarkable in study [42] as it is of about $11 \%$. The authors also gave midpoint data for both studies from which it can be stated that the latent heat of fusion did not follow any clear pattern in any of the studies, as in both it increases and decreases randomly, with more remarkable variations in study [42], which is the one were a more important latent heat decrease was observed.

\subsection{Metal alloys}


Table 7 presents the results of the study by Sun et al. [43] on an aluminium-magnesium-zinc alloy that melts at around $450{ }^{\circ} \mathrm{C}$ and was cycled 1000 times. The melting temperature of the alloy corresponds to the onset temperature obtained by drawing a line at the point of maximum slope of the leading edge of the DSC peak and extrapolating the base line on the same side as the leading edge of the peak. The latent heat of fusion was calculated as the area under the peak by numerical integration. They cycled the PCM using a thermostatic chamber and the thermal properties were determined with a Q10-V5.1-Build 191 DSC, performing the analysis in the 298 $-823{ }^{\circ} \mathrm{C}$ range with a constant heating rate of $10{ }^{\circ} \mathrm{C} / \mathrm{min}$ under a $80 \mathrm{ml} / \mathrm{min}$ nitrogen stream at atmospheric pressure. Results after the 1000 cycles show an $11 \%$ loss on the heat storage capacity and a $3{ }^{\circ} \mathrm{C}$ drop on the melting temperature.

\subsection{Inorganic eutectics}

The cycling methodology and results of seven inorganic eutectics are shown in Table 8. The melting points of the studied eutectics range from $20^{\circ} \mathrm{C}$ to $78{ }^{\circ} \mathrm{C}$, and all of them were cycled 1000 times.

None of the authors that studied the inorganic eutectics presented in Table 8 gave information about the procedure followed to analyse the thermal properties of the materials. The cycling process and the parameter calculation methods were neither explained in any of the studies.

Kimura and Kai [46] studied the thermal stability of different $\mathrm{CaCl}_{2}$ compounds using the same Perkin Elmer DSC 2. They showed the melting point and heat of fusion values before and after the 1000 cycles.

Nagano et al. [47] did not specify the DSC model used in the study of the $\operatorname{Mg}\left(\mathrm{NO}_{3}\right)_{2}$ compound and they presented only the data obtained before cycling the samples. In addition, they also gave the initial value of the latent heat of crystallization. Therefore, conclusions on what happens to these samples when cycled cannot be drawn.

\section{Comparison by methodology and equipment}

Thermal cycling stability tests are nowadays performed using a wide variety of equipment and setups. Some researchers use DSC, but ovens, thermostatic baths/chambers and electric hot plates are other kind of equipment also employed to perform PCM cycling tests. Other more 
specific instruments are thermal cyclers. Up to now, thermal cyclers are designed for biomedical applications, though the available temperature range is set from 0 to $100{ }^{\circ} \mathrm{C}$.

\subsection{Equipment}

Twenty nine different devices and setups were used to study the thermal stability of fifty eight PCM. Seventeen of these twenty nine devices and setups were differential scanning calorimeters (DSC), while the other $41 \%$ were setups exclusively designed to cycle the PCM. Only half of the seventeen DSCs were used for both sample cycling and properties analysing, being the function of the other half to just measure the thermal properties of the already cycled PCM. On the other hand, all the non-DSC equipment displayed in Table 9 were just used to cycle the samples. Regarding these non-DSC setups, it is important to point out here that they have been classified according to the main operational equipment used in each setup; hence, setups included in a same group may have important configuration differences.

The thermal properties of the materials were in all cases measured by DSC except in Porosini's [45] study, were the data was logged directly from the thermostatic chamber setup.

Taking a deeper look on the data presented in Table 9, the huge variety of equipment used to cycle and analyse the PCM does not show any pattern for which one material type is cycled in one concrete setup or DSC and its properties measured in a specific DSC. Hence, no standard is followed by any of the authors when selecting the equipment to conduct their studies, therefore it is reasonable to think that every author studied the thermal stability of each PCM using the equipment he disposed of.

\subsection{Cycling method}

The cycling method used to analyse the PCM is explained in thirty out of the thirty eight consulted papers. As Table 10 shows, there are two main methods used by the authors: the pyramid method, by which the samples are heated and cooled consecutively, with no isothermal stages amid; and the dynamic method, that stabilizes the PCM samples with isothermal stages before and after every heating and cooling segment. The pyramid method is the most used cycling method, applied by the $83 \%$ of the authors, while the dynamic method is only used in five of the thirty papers that reported the followed cycling procedure. However, five different cool down modes are found within the pyramid method. The cool down at room temperature 
mode is used in ten papers, which makes it the most used one. The constant rate cooling is used in seven studies, but again different cool down rates in the range $0.7^{\circ} \mathrm{C} / \mathrm{min}-10{ }^{\circ} \mathrm{C} / \mathrm{min}$ are used by the authors. The other three cooling modes used consisted on cooling in a refrigeration plant, applied in four studies; cooling down at the chamber temperature, which means to cool the sample down in the same chamber where the PCM is heated and it is used by four authors as well; and cooling down in a water bath, mode used by Sun et al. [57] to solidify the Al-34\%Mg$6 \% \mathrm{Zn}$ alloy.

Regarding the dynamic method, three different constant rates are used by the authors in the 5 ${ }^{\circ} \mathrm{C} / \mathrm{min}-10{ }^{\circ} \mathrm{C} / \mathrm{min}$ range. In addition, and contrary to the different cool down modes of the pyramid method, both heating and cooling stages have the same flow rate.

Despite of the huge data amount exposed in Table 10, no clear pattern for which a specific material has to be cycled by any of the methods and its different heating/cooling modes is found.

\subsection{Analysis method}

The analysis methods chosen to measure the PCM thermal properties was reported in twenty five out of the thirty eight consulted papers and are shown in Table 11 . The other $34 \%$ of the authors did not enclose any information on how the measurements were developed.

The same method types used to cycle the samples are also the ones used by the authors to measure the thermal properties of the PCM: the dynamic method and the pyramid method. The dynamic method is only used in the two different studies by Sharma et al. [26,27], where paraffin wax 53, acetamide and stearic acid were analysed. The pyramid method was the most used, but different heating/cooling rates were applied to analyse the PCM. Zhang et al. [32] measured with a differential scanning calorimeter (DSC) the lauric/palmitc eutectic's thermal properties heating and cooling the samples at a constant rate of $3{ }^{\circ} \mathrm{C} / \mathrm{min}$. Twenty two different PCM of mostly all family types (organic, inorganic, paraffin and eutectics) were analysed under a $5{ }^{\circ} \mathrm{C} / \mathrm{min}$ heating/cooling constant rate by eight different authors in eleven studies, which makes it the most common of the heating/cooling rates used. Furthermore, seven different calorimeters were used to do it, being six of them DSC apparatus and the other one a nonspecified calorimeter. Calcium chloride hexahydrate's thermal stability was evaluated using a 7 ${ }^{\circ} \mathrm{C} /$ min constant heating/cooling rate by Tyagi et al. [48], which indeed was the only researcher to select such method. A constant heating/cooling rate of $10^{\circ} \mathrm{C} / \mathrm{min}$ was used to measure the thermal properties of eleven different type PCM (organic, inorganic and eutectics, including the only metal alloy studied) in seven different studies where seven different DSC apparatus were 
used as well. Finally, Sharma et al. [38] analysed fifty time cycled urea using the ramp method as well, but no information on the concrete heating/cooling rate used was reported in their study.

The huge variety on the analysis conditions clearly states that there is no common pattern that specifies the conditions in which each one of the material types has to be studied.

\subsection{Number of cycles}

Table 12 classifies the PCM as a function of the number of performed cycles in five different cycle ranges, from 0 up to 6000 cycles. As this classification shows, a similar number of PCM is cycled in the first four ranges, being the higher 3001-6000 range the less used one. The clearest fact that can be withdrawn here is that organic PCM (both organic compounds and eutectics) are more often cycled in the low range area, 0 - 500 cycles. However, results clearly show that it does not exist any general standard on the number of cycles a concrete material has to undergo, and that explains, for example, that some organic materials were also cycled more than 3000 times or that $\mathrm{CaCl}_{2} \cdot 6 \mathrm{H}_{2} \mathrm{O}$ is found in the lowest (0-100), the middle (501-1000) and the highest (3001-6000) cycle time ranges. Thus, and again, no pattern was found when analysing the cited results by the undergone number of cycles.

\section{Conclusions}

A review on thermal cycling stability testing has been performed for paraffins, organic materials, salt hydrates, metal alloys, and inorganic eutectics which are commonly used as PCM.

Conclusions are separated in four main aspects according to the main trends to consider when studying the thermal stability of a PCM. These most important parameters are the equipment to cycle the materials, the PCM characterization techniques, the number of cycles to perform and the thermal cycling method.

- Regarding the equipment used and as shown in Table 9, DSC is the most common instrument used to analyse the samples, but just $50 \%$ of the cited authors also use it for cycling. These numbers lead to the first important conclusion that can be withdrawn 
from this study, which is the lack of a standard that specifies the most useful equipment to perform thermal stability studies.

- The results displayed in the former tables show that DSC is the equipment selected by all authors for PCM thermal characterization. The DSC selection is expected since traditionally DSC has been the most powerful and the most used technique for this purpose. Regarding the analysis conditions, various heating/cooling rates have been used to measure the thermal properties and the $10^{\circ} \mathrm{C} / \mathrm{min}$ has been found as the most applied one. That is contrary to the suggestions given by studies $[3,64]$, where low rates are strongly recommended.

- Two main cycling methods, the pyramid and the dynamic, have been found as the most used ones within all the consulted papers. Moreover, the pyramid method is, for far, the most applied one. However, a huge variety of heating rates were used with both methods, being the $5{ }^{\circ} \mathrm{C} / \mathrm{min}, 7{ }^{\circ} \mathrm{C} / \mathrm{min}$ and $10{ }^{\circ} \mathrm{C} / \mathrm{min}$ the main chosen ones. This variety of analysis conditions observed leads to conclude that it does not exist any standard methodology to cycle PCM.

- As Table 11 shows, a large variety of cycle ranges has been selected by the different authors and no criteria regarding the PCM family type nor the application are followed in neither case. Thus, and once again, there is a lack of a general standard specifying the number of cycles a specific material has to undergo.

The missing of a general standard for this type of experiments is also observed when different authors or even the same authors perform experiments under the same conditions and obtain different results. No common pattern has been found either when presenting their results. Authors present melting temperature, latent heat of fusion or latent heat of crystallization randomly. Information about the method used, or the equipment is also missing in some of the papers reviewed. Comparing results obtained under the same exact conditions and evaluating them with the same exact methods is the only way by which the results can be analysed and improvements can be applied to obtain better and more accurate parameter values, otherwise, it is impossible to make comparisons if every author has each own criteria when presenting results. 
It is mandatory to conclude that a common standard for thermal cycling stability tests would be very appreciated in the scientific community.

\section{Acknowledgements}

The research leading to these results has received funding from the European Commission Seventh Framework Programme (FP/2007-2013) under grant agreement n ${ }^{\circ}$ PIRSES-GA-2013610692 (INNOSTORAGE). Furthermore, the work is partially funded by the Spanish government (ENE2011-28269-C03-02 and ENE2011-22722). The authors would like to thank the Catalan Government for the quality accreditation given to their research groups GREA (2014 SGR 123) and DIOPMA (2014 SGR 1543). Aran Solé would like to thank the Departament d'Universitats, Recerca i Societat de la Informació de la Generalitat de Catalunya for her research fellowship.

\section{References}

1. International Energy Agency (IEA). Technology Roadmap. Energy Storage 2014.

2. Kousksou T., Bruel P., Jamil A., El Rhafiki T., Zeraouli Y. Energy storage: Applications and challenges. Solar Energy Materials and Solar Cells, 2014; 120: 59-80.

3. Mehling H., Cabeza L.F. Heat and cold storage with PCM. Springer, Berlin 2008

4. Memon S.A. Phase change materials integrated in building walls: A state of the art review. Renewable and sustainable energy reviews, 2014; 31: 870-906.

5. Pielichowska K., Pielichowski K. Phase change materials for thermal energy storage. Progress in Material Science, 2014; 67: 67-123.

6. Sharma A., Tyagi V.V., Chen C.R., Buddhi D. Review on thermal energy storage with phase change materials and applications. Renewable and Sustainable Energy Reviews, 2009; 13: 318-345.

7. Li M., Wu Z. A review of intercalation composite phase change material: Preparation, structure and properties. Renewable ans Sustainable Energy Reviews 2012; 16: 20942101.

8. Cai Y., Song L., He Q., Yang D., Hu Y. Preparation, thermal and flammability properties of a novel form-stable phase change materials based on high density polyethylene/polyethylene-co-vinyl acetate)/organophilic montmorillonite nanocomposites/paraffin compounds. Energy conversion and management, 2008; 49: 2055-2062. 
9. Jamekhorshid A., Sadrameli S.M., Farid M. A review of microencapsulation methods of phase change materials (PCMs) as a thermal energy storage (TES) medium. Renewable and Sustainable Energy Reviews, 2014; 31:531-542.

10. Kenisarin M.M., Kenisarina K.M. Form-stable phase change materials for thermal energy storage. Renewable and Sustainable Energy Reviews 16 (2012) 1999-2040.

11. Solé A., Neumann H., Niedermaier S., Martorell I., Schossig P., Cabeza L.F. Stability of sugar alcohols as PCM for thermal energy storage. Solar Energy Materials and Solar Cells, 2014; 126: 125-134.

12. Sarier N., Onder E. Organic phase change materials and their textile applications: An overview. Thermochimica Acta 2012; 540: 7-60.

13. Delgado M., Lázaro A., Mazo J., Zalba B. Review on phase change material emulsions and microencapsulated phase change material slurries: Materials, heat transfer studies and applications. Renewable and Sustainable Energy Reviews 2012; 16: 253- 273.

14. Farid M.M., Khudhair A., Razack S.A.K., Al-Hallaj S. A review on phase change energy storage: materials and applications. Energy Conversion and Management 2004; 45: $1597-1615$.

15. Kenisarin M., Mahkamov K. Solar energy storage using phase change materials. Renewable and Sustainable Energy Reviews 2007; 11:1913-1965.

16. Tyagia V.V., Kaushika S.C., Tyagib S.K., Akiyamac T. Development of phase change materials based microencapsulated technology for buildings: A review. Renewable and Sustainable Energy Reviews 2011; 15:1373-1391

17. Saito A. Recent advances in research on cold thermal energy storage. International Journal of Refrigeration, 2002; 25:177-189.

18. Mahiana O., Kianifara A., Kalogirou A.S., Pop I., Wongwises S. A review of the applications of nanofluids in solar energy. International Journal of Heat and Mass Transfer 2013; 57:582-594.

19. Oró E., De Gracia A., Castell A., Farid M.M., Cabeza L.F. Review on phase change materials (PCMs) for cold thermal energy storage applications. Applied Energy, 2012; 99:513-533.

20. Pinel P., Cruickshank C.A., Beausoleil-Morrison I., Wills A. A review of available methods for seasonal storage of solar thermal energy in residential applications. Renewable and Sustainable Energy Reviews, 2011; 15:3341-3359.

21. Zhang P., Ma Z.W., Wang R.Z. An overview of phase change material slurries: MPCS and CHS. Renewable and Sustainable Energy Reviews, 2010; 14:598-614.

22. Rathod M.K., Banerjee J. Thermal stability of phase change materials used in latent heat energy storage systems: A review. Renewable and Sustainable Energy Reviews, 2013; $18: 246-258$. 
23. Kenisarin M.M., Kenisarina K.M. Form-stable phase change materials for thermal energy storage. Renewable and Sustainable Energy Reviews, 2012; 16:1999- 2040.

24. Chen Z., Fang G. Preparation and heat transfer characteristics of microencapsulated phase change material slurry: A review. Renewable and Sustainable Energy Reviews, $2011 ; 15: 4624-4632$.

25. Tatsidjodoung P., Le Pierrès N, Luo L. A review of potential materials for thermal energy storage in building applications. Renewable and Sustainable Energy Reviews, $2013 ; 18: 327-349$.

26. Sharma S.D., Buddhi D., Sawhney R.L. Accelerated thermal cycle test of latent heat storage materials. Solar Energy, 1999; 66(6): 483-490.

27. Sharma A., Sharma S.D., Buddhi D. Accelerated thermal cycle test of acetamide, stearic acid and paraffin wax for solar thermal latent heat storage applications. Energy Conversion and Management, 2002; 43: 1923-1930.

28. Hadjieva M., St Kanev., Argirov J. Thermophysical properties of some paraffins applicable to thermal energy storage. Solar Energy Materials and Solar Cells, 1992; 27: 181-187.

29. Shukla A., Buddhi D., Sawhney R.L. Thermal cycling test of few selected inorganic and organic phase change materials. Renewable Energy, 2008; 33: 2606-2614.

30. Alkan C., Kaya K., Sari A. Preparation, thermal properties and thermal reliability of form-stable paraffin/polypropylene composite for thermal energy storage. Journal of Polymers and the Environment, 2009; 17: 254-258.

31. Sari A., Eroglu R., Biçer A., Karaipekli A. Synthesis and thermal energy storage properties of erythritol tetrastearate and erythritol tetrapalmitate. Chemical Engineering and Technology, 2011; 34(1): 87-92.

32. Zhang J-J., Zhang J-L., He S-M., Wu K-Z., Liu X-D. Thermal studies on the solid-liquid phase transition in binary systems of fatty acids. Thermochimica Acta, 2001; 369: 157160.

33. Sari A. Thermal reliability test of some fatty acids as PCMs used for solar thermal latent heat storage applications. Energy Conversion and Management, 2003; 44: 2277-2287.

34. Sari A., Karaipekli A. Preparation, thermal properties and thermal reliability of capric acid/expanded perlite composite for thermal energy storage. Materials Chemistry and Physics, 2008; 109: 459-464.

35. Karaipekli A., Sari A., Kaygusuz K. Thermal properties and thermal reliability of capric acid/stearic acid mixture for latent heat thermal energy storage. Energy Sources 2009; 109: 459-464. 
36. Abhat A., Malatidis N.A., Determination of properties of heat of fusion storage materials for low temperature applications. In: First IEA conference on new energy conservation technologies and their commercialization, Berlin, FRG: Springer, 1981.

37. Hasan A., Sayigh A.A. Some fatty acids as phase-change thermal energy storage materials. Renewable Energy, 1994; 4(1): 69-76.

38. Sharma A., Sharma S.D., Buddhi D., Sawhney R.L. Thermal cycle test of urea for latent heat storage applications. International Journal of Energy Resources, 2001; 25: 465-468.

39. Nikolic R., Marinovic-Cincovic M., Gadzuric S., Zsigrai I.J. New materials for solar thermal storage solid/liquid transitions in fatty acid esters. Solar Energy Materials \& Solar Cells, 2003; 79: 285-292.

40. Sari A., Kaygusuz K. Some fatty acids used for latent heat storage: thermal stability and corrosion of metals with respect to thermal cycling. Renewable Energy, 2003; 28: 939948.

41. Sari A., Karaipekli A. Preparation, thermal properties and thermal reliability of palmitic acid/expanded graphite composite as form-stable PCM for thermal energy storage. Solar Energy Materials and Cells, 2009; 93: 571-576.

42. El-Sebaii A.A., Al-Amir S., Al-Marzouki F.M., Faidah A.S., Al-Ghamdi A.A., Al-Heniti $\mathrm{S}$. Fast termal cycling of acetanilide and magnesium chloride hexahydrate for indoor solar cooking. Energy Conversion and Management, 2009; 50: 3104-3111.

43. Kimura H., Kai J. Feasibility of trichlorofluoromethane (CCl3F, R11) heptadecahydrate as a heat storage material. Energy Conversion and Management, 1985; 25(2): 179-186.

44. Fellchenfeld H., Sarig S. Calcium chloride hexahydrate: a phase-changing material for energy storage. Industrial \& Engineering Chemistry Product Research and Development, 1985; 24: 130-133.

45. Porosini F.C. Salt hydrates used for latent heat storage: corrosion of metals and reliability of thermal performance. Solar Energy, 1988; 41: 193-197.

46. Kimura H., Kai J. Mixture of calcium chloride hexahydrate with some salt hydrates or anhydrous salts as latent heat storage materials. Energy Conversion and Management, 1988; 28(3): 197-200.

47. Nagano K., Ogawa K., Mochida T., Hayashi K., Ogoshi H. Thermal characteristics of magnesium nitrate hexahydrate and magnesium chloride hexahydrate mixture as a phase change material for effective utilization of urban waste heat. Applied Thermal Engineering, 2004; 24(2-3): 221-232.

48. Tyagi V.V., Buddhi D. Thermal cycling testing of calcium chloride hexahydrate as a possible PCM for latent heat storage. Solar Energy Materials \& Solar Cells, 2008; 92(8): 891-899. 
49. Jotshi C.K. Thermal storage in ammonium alum/ammonium nitrate eutectic for solar space heating applications. Solar Energy Engineering, 1998; 120: 20-24.

50. Dimaano M., Escoto A. Preliminary assessment of a mixture of capric acid and lauric acid for low temperature thermal energy storage. Energy, 1998; 23: 421-427.

51. Sari A., Sari H., Onal A. Thermal properties and thermal reliability of eutectic mixtures of some fatty acids as latent heat storage materials. Energy Conversion and Management, 2004; 45: 365-376.

52. Sari A. Eutectic mixtures of some fatty acids for low temperature solar heating applications: thermal properties and thermal reliability. Applied Thermal Engineering, 2005; 25: 2100-2107.

53. Shilei L., Neng Z., Guohui F. Eutectic mixture of capric acid and lauric acid applied in building wallboards for heat energy storage. Energy and Buildings, 2006; 38: 708-711.

54. Karaipekli A., Sari A. Capric-myristic acid/expanded perlite composite as form-stable phase change material for latent heat thermal energy storage. Renewable Energy, 2008; 33: 2599-2605.

55. Sari A., Biçer A., Karaipekli A., Alkan C., Karadag A. Synthesis, thermal energy storage properties and thermal reliability of some fatty acid esters with glycerol as novel solidliquid phase change materials. Solar Energy Materials and Solar Cells, 2010; 94: 17111715.

56. Zuo J.,Li W., Weng L. Thermal performance of caprylic acid/1-dodecanol eutectic mixture as phase change material (PCM). Energy and Buildings, 2011; 43: 207-210.

57. Sun J.Q., Zhang R.Y., Liu Z.P., Lu G.H. Thermal reliability test of Al-34\%Mg-6\%Zn alloy as latent heat storage material and corrosion of metal with respect to thermal cycling. Energy Conversion and Management, 2007; 48(2): 619-624.

58. El-Sebaii A.A., Al-Heniti S., Al-Ghamdi A.A., Al-Marzouki F. One thousand thermal cycles of magnesium chloride hexahydrate as a promising PCM for indoor solar cooking. Energy Conversion and Management, 2011; 52: 1771-1777.

59. Marks S. An investigation of the thermal energy storage capacity of glauber's salt with respect to thermal cycling. Solar Energy, 1980; 25: 225-258.

60. Kimura H., Kai J. Phase change stability of $\mathrm{CaCl}_{2} \cdot 6 \mathrm{H}_{2} \mathrm{O}$. Solar Energy, 1984; 33(1): 4955.

61. Wada T., Yamamoto R., Matsuo Y. Heat storage capacity of sodium acetate trihydrate during thermal cycling. Solar Energy, 1984; 33(3/4): 373-375.

62. Silakhori M., Naghavi M.S., Metselaar H.S.C., Mahlia T.M.I., Fauzi H., Mehrali M. Accelerated Thermal Cycling Test of Microencapsulated Paraffin Wax/Polyaniline Made by Simple Preparation Method for Solar Thermal Energy Storage. Materials, 2013; 6: 1608-1620. 
63. Jingyu H., Shilei L., Xiangfei K., Shangbao L., Yiran I. Form-Stable Phase Change Materials Based on Eutectic Mixture of Tetradecanol and Fatty Acids for Building Energy Storage: Preparation and Performance Analysis. Materials, 2013; 6: 4758- 4775.

64. Barreneche C., Solé A., Miró L., Martorell I., Fernándex A.I., Cabeza L.F. Study on differential scanning calorimetry analysis with two operation modes and organic and inorganic phase change material (PCM). Thermochimica Acta, 2013; 553: 23-26. 
Table 1. Advantages and disadvantages of organic and inorganic PCM.

\begin{tabular}{lll}
\hline & \multicolumn{1}{c}{ Organic } & \multicolumn{1}{c}{ Inorganic } \\
\hline \multirow{3}{*}{ Advantages } & Non-corrosive & Higher phase change enthalpy \\
& Low or no subcooling & Higher conductivity \\
& Cycling stability & Non-flammable \\
\hline \multirow{2}{*}{ Disadvantages } & Lower phase change enthalpy & Subcooling \\
& Lower thermal conductivity & Corrosive \\
& Flammable & Phase separation \\
& & Lack of cycling stability \\
\hline Price $(€ / \mathrm{kg})$ & $6.5-13$ & $3-8$ \\
\hline
\end{tabular}


Table 2. Review on the properties listed in the literature.

\begin{tabular}{|c|c|c|c|c|c|c|}
\hline Reference & $\begin{array}{c}\text { Mention on thermal } \\
\text { stability }\end{array}$ & $\begin{array}{c}\text { Mention on thermal cycling } \\
\text { stability }\end{array}$ & $\begin{array}{c}\text { Mention on thermal } \\
\text { cycles }\end{array}$ & Cycle range & $\begin{array}{c}\text { Data } \\
\text { availability }\end{array}$ & Data presented \\
\hline$[12]$ & +++ & +++ & +++ & $1000-5000$ & + & $\begin{array}{c}\text { SEM Images, DSC data,TGA } \\
\text { data }\end{array}$ \\
\hline [13] & + & ++ & +++ & $1000-5000$ & + & NDA \\
\hline$[14]$ & +++ & ++ & ++ & NDA & - & NDA \\
\hline$[15]$ & + & + & + & NDA & - & NDA \\
\hline$[16]$ & ++ & +++ & +++ & $5-100$ & ++ & $\begin{array}{c}\text { SEM Images, DSC data,TGA } \\
\text { data }\end{array}$ \\
\hline$[17]$ & + & - & - & NDA & - & NDA \\
\hline$[18]$ & - & - & - & NDA & - & NDA \\
\hline$[19]$ & ++ & ++ & +++ & NDA & - & NDA \\
\hline$[20]$ & + & + & + & NDA & - & NDA \\
\hline$[21]$ & + & ++ & ++ & NDA & ++ & $\begin{array}{c}\text { SEM Images, DSC data,TGA } \\
\text { data }\end{array}$ \\
\hline$[22]$ & +++ & +++ & +++ & $1000-5000$ & +++ & $\begin{array}{c}\text { SEM Images, DSC data,TGA } \\
\text { data }\end{array}$ \\
\hline$[23]$ & +++ & +++ & +++ & $1000-5000$ & +++ & $\begin{array}{c}\text { SEM Images, DSC data,TGA } \\
\text { data }\end{array}$ \\
\hline$[24]$ & +++ & ++ & +++ & $5-5000$ & ++++ & Particle Size distribution \\
\hline$[25]$ & ++ & + & + & NDA & - & NDA \\
\hline
\end{tabular}


Table 3. Melting point and latent heat of thermal cycled paraffins

\begin{tabular}{|c|c|c|c|c|c|c|c|c|c|c|c|}
\hline \multirow[b]{2}{*}{$\begin{array}{l}\text { Sr. } \\
\text { no }^{\circ}\end{array}$} & \multirow[b]{2}{*}{ PCM } & \multicolumn{7}{|c|}{ Analytical parameters } & \multirow[b]{2}{*}{$\begin{array}{l}\text { 1)Thermal equipment } \\
\text { 2) Cycling equipment }\end{array}$} & \multirow[b]{2}{*}{ Analysis Method } & \multirow[b]{2}{*}{ Reference } \\
\hline & & $\begin{array}{c}\text { Initial } \\
\text { melting } \\
\text { point }\left({ }^{\circ} \mathrm{C}\right)\end{array}$ & $\begin{array}{c}\text { Final } \\
\text { melting } \\
\text { point }\left({ }^{\circ} \mathrm{C}\right)\end{array}$ & $\begin{array}{c}\text { Initial } \\
\text { latent } \\
\text { heat of } \\
\text { fusion } \\
(\mathrm{J} / \mathrm{g})\end{array}$ & $\begin{array}{c}\text { Final } \\
\text { latent } \\
\text { heat of } \\
\text { fusion } \\
(\mathrm{J} / \mathrm{g})\end{array}$ & $\begin{array}{l}\text { Thermal } \\
\text { cycles }\end{array}$ & $\begin{array}{c}\text { Initial } \\
\text { latent } \\
\text { heat of } \\
\text { crystalliz } \\
\text { ation } \\
\text { (J/g) }\end{array}$ & $\begin{array}{c}\text { Final } \\
\text { latent } \\
\text { heat of } \\
\text { crystalliz } \\
\text { ation } \\
\text { (J/g) }\end{array}$ & & & \\
\hline 1 & $\begin{array}{c}\text { Paraffin }(70 w t \%)+ \\
\text { Polypropylene }(30 w t \%)\end{array}$ & 44.77 & 45.52 & 136.16 & 116.12 & 3000 & 136.59 & 116.78 & $\begin{array}{l}\text { 1) Setaram DSC } 131 \\
\text { 2) Electric hot plate } \\
\text { setup }\end{array}$ & $\begin{array}{l}5^{\circ} \mathrm{C} / \mathrm{min} \text { heating rate under } \\
\text { a constant stream of argon } \\
\text { at a flow rate of } 60 \mathrm{~mL} / \mathrm{min} \\
\text { in DSC }\end{array}$ & $\begin{array}{l}\text { Alkan et al. } \\
\qquad[30]\end{array}$ \\
\hline 2 & $\begin{array}{l}\text { Paraffin }\left(\mathrm{C}_{22} \mathrm{H}_{44.1}\right) \\
\text { (technical grade) }\end{array}$ & 47.1 & 46.6 & 166 & 163 & 900 & - & - & $\begin{array}{l}\text { 1) DSC with Mettler TA } \\
3000 \text { system } \\
\text { 2) Thermostatic bath } \\
\text { setup }\end{array}$ & No info & $\begin{array}{l}\text { Hadjieva et } \\
\text { al. [28] }\end{array}$ \\
\hline 3 & $\begin{array}{c}\text { Paraffin }\left(\mathrm{C}_{23} \mathrm{H}_{48.4}\right) \\
\text { (technical grade) }\end{array}$ & 57.1 & 57.8 & 220 & 224 & 900 & - & - & $\begin{array}{l}\text { 1) DSC with Mettler TA } \\
3000 \text { system } \\
\text { 2) Thermostatic bath } \\
\text { setup }\end{array}$ & No info & $\begin{array}{c}\text { Hadjieva et } \\
\text { al. [28] }\end{array}$ \\
\hline \multirow[t]{2}{*}{4} & \multirow[t]{2}{*}{$\begin{array}{c}\text { Paraffin wax } 53 \\
\text { (commercial grade) }\end{array}$} & 53 & 53 & 184 & 165 & 300 & - & - & $\begin{array}{l}\text { 1) Rheometric Scientific } \\
\text { Ltd. DSC } \\
\text { 2) Electric hot plate } \\
\text { setup. }\end{array}$ & $\begin{array}{l}\text { Isothermal-ramp- } \\
\text { isothermal method was } \\
\text { used in DSC }\end{array}$ & $\begin{array}{c}\text { Sharma et } \\
\text { al. [26] }\end{array}$ \\
\hline & & 53 & 50 & 184 & 136 & 1500 & - & - & $\begin{array}{c}\text { 1) Rheometric Scientific } \\
\text { Ltd. DSC }\end{array}$ & $\begin{array}{l}\text { Isothermal-ramp- } \\
\text { isothermal method was }\end{array}$ & $\begin{array}{c}\text { Sharma et } \\
\text { al. [27] }\end{array}$ \\
\hline
\end{tabular}




\begin{tabular}{|c|c|c|c|c|c|c|c|c|c|c|c|}
\hline & & & & & & & & & $\begin{array}{l}\text { 2) Electric hot plate } \\
\text { setup. }\end{array}$ & used in DSC & \\
\hline 5 & Paraffin wax 58-60 & 58.27 & 55 & 129.8 & 102 & 600 & - & - & $\begin{array}{l}\text { 1) Rheometric Scientific } \\
\text { Ltd. DSC } \\
\text { 2) Oven. }\end{array}$ & No info & $\begin{array}{l}\text { Shukla et } \\
\text { al. [29] }\end{array}$ \\
\hline 6 & Paraffin wax 60-62 & 57.78 & 59 & 129.7 & 109 & 600 & - & - & $\begin{array}{l}\text { 1) Rheometric Scientific } \\
\text { Ltd. DSC } \\
\text { 2) Oven. }\end{array}$ & No info. & $\begin{array}{l}\text { Shukla et } \\
\text { al. [29] }\end{array}$ \\
\hline 7 & $\begin{array}{l}\mathrm{n} \text { - } \\
\text { Heptadecane/polymethyl } \\
\text { methacrylate }\left(\mathrm{C}_{17} \mathrm{H}_{36}\right)\end{array}$ & 18.4 & 18.9 & 84.7 & 94.5 & 5000 & 18.2 & 19.1 & $\begin{array}{l}\text { 1) Perkin Elmer } \\
\text { Diamond DSC } \\
\text { 2) Electric hot plate } \\
\text { setup }\end{array}$ & $\begin{array}{l}\text { The heating and cooling } \\
\text { rate in DSC was } 5^{\circ} \mathrm{C} / \mathrm{min} \\
\text { in argon atmosphere }\end{array}$ & $\begin{array}{l}\text { Sari et al. } \\
\qquad[31]\end{array}$ \\
\hline 8 & $\begin{array}{c}\text { Microencapsulated } \\
\text { paraffin wax } 53 \\
(0.1 \mathrm{~g}) / \text { polyaniline }(0.9 \mathrm{~g})\end{array}$ & 53.2 & 53.4 & 31 & 30.5 & 1000 & 32.6 & 30.7 & $\begin{array}{l}\text { 1) Thermal box with } \\
\text { heater and cooler setup } \\
\text { 2) Mettler Toledo 820C } \\
\text { DSC }\end{array}$ & No info & $\begin{array}{l}\text { Silakhori et } \\
\text { al. [62] }\end{array}$ \\
\hline 9 & $\begin{array}{c}\text { Microencapsulated } \\
\text { paraffin wax } 53 \\
(0.2 \mathrm{~g}) / \text { polyaniline }(0.8 \mathrm{~g})\end{array}$ & 53.8 & 53.4 & 65.1 & 60.5 & 1000 & 66.4 & 61 & $\begin{array}{l}\text { 1) Thermal box with } \\
\text { heater and cooler setup } \\
\text { 2) Mettler Toledo } 820 \mathrm{C} \\
\text { DSC }\end{array}$ & No info & $\begin{array}{l}\text { Silakhori et } \\
\text { al. [62] }\end{array}$ \\
\hline
\end{tabular}


Table 4. Melting point and latent heat of thermal cycled non-paraffin non-eutectic organic materials

\begin{tabular}{|c|c|c|c|c|c|c|c|c|c|c|c|}
\hline \multirow[b]{2}{*}{$\begin{array}{l}\text { Sr. } \\
n^{\circ}\end{array}$} & \multirow[b]{2}{*}{ PCM } & \multicolumn{7}{|c|}{ Analytical parameters } & \multirow[b]{2}{*}{$\begin{array}{l}\text { 1) Thermal equipment } \\
\text { 2) Cycling equipment }\end{array}$} & \multirow[b]{2}{*}{ Analysis method } & \multirow[b]{2}{*}{ Reference } \\
\hline & & $\begin{array}{c}\text { Initial } \\
\text { melting } \\
\text { point } \\
\left({ }^{\circ} \mathrm{C}\right)\end{array}$ & $\begin{array}{c}\text { Final } \\
\text { melting } \\
\text { point }\left({ }^{\circ} \mathrm{C}\right)\end{array}$ & $\begin{array}{c}\text { Initial } \\
\text { latent } \\
\text { heat of } \\
\text { fusion } \\
(\mathrm{J} / \mathrm{g})\end{array}$ & $\begin{array}{c}\text { Final } \\
\text { latent } \\
\text { heat of } \\
\text { fusion } \\
(\mathrm{J} / \mathrm{g})\end{array}$ & $\begin{array}{l}\text { Therma } \\
\text { l cycles }\end{array}$ & $\begin{array}{c}\text { Initial } \\
\text { latent heat } \\
\text { of } \\
\text { crystallizati } \\
\text { on }(\mathrm{J} / \mathrm{g})\end{array}$ & $\begin{array}{l}\text { Final latent } \\
\text { heat of } \\
\text { crystallizati } \\
\text { on }(\mathrm{J} / \mathrm{g})\end{array}$ & & & \\
\hline \multirow{2}{*}{1} & \multirow{2}{*}{$\begin{array}{c}\text { Acetamide } \\
\left(\mathrm{CH}_{3} \mathrm{CONH}_{2}\right)\end{array}$} & 82 & 81 & 263 & 241 & 300 & - & - & $\begin{array}{l}\text { 1) Rheometric Scientific Ltd. } \\
\qquad \text { DSC } \\
\text { 2) Electric hot plate setup }\end{array}$ & $\begin{array}{l}\text { Isothermal-ramp-isothermal } \\
\text { method was used in DSC }\end{array}$ & $\begin{array}{l}\text { Sharma et } \\
\text { al. [26] }\end{array}$ \\
\hline & & 82 & 84 & 263 & 260 & 1500 & - & - & $\begin{array}{l}\text { 1) Rheometric Scientific Ltd. } \\
\text { DSC } \\
\text { 2) Electric hot plate setup }\end{array}$ & $\begin{array}{l}\text { Isothermal-ramp-isothermal } \\
\text { method was used in DSC }\end{array}$ & $\begin{array}{l}\text { Sharma et } \\
\text { al. [27] }\end{array}$ \\
\hline 2 & $\begin{array}{l}\text { Acetanilide } \\
\left(\mathrm{C}_{8} \mathrm{H}_{9} \mathrm{NO}\right)\end{array}$ & 113 & 106 & 169.4 & 154 & 500 & - & - & Shimadzu DSC-60 & $\begin{array}{l}\text { The samples were cycled in the } \\
\mathrm{DSC} \text { at } 10 \mathrm{~K} / \mathrm{min} \text { between } \\
\text { ambient temperature and } 200 \\
{ }^{\circ} \mathrm{C} \text {. The analysis was carried out } \\
\text { under a constant nitrogen } \\
\text { stream of } 50 \mathrm{mil} / \mathrm{min} \text {. The } \\
\text { samples are heated at a constant } \\
\text { rate }\end{array}$ & $\begin{array}{l}\text { El-Sebaii et } \\
\text { al. [42] }\end{array}$ \\
\hline 3 & $\begin{array}{l}\text { Capric acid (55 } \\
\text { wt } \%)+ \text { expanded } \\
\text { perlite }(45 \mathrm{wt} \%)\end{array}$ & 31.80 & 30.25 & 98.12 & 95.54 & 5000 & 90.06 & 90.60 & $\begin{array}{l}\text { 1) Setaram DSC } 131 \\
\text { 2) Electric hot plate setup }\end{array}$ & $\begin{array}{l}\text { The heating rate in DSC was } 5 \\
{ }^{\circ} \mathrm{C} / \mathrm{min} \text {, under a constant stream } \\
\text { of argon at atmospheric } \\
\text { pressure }\end{array}$ & $\begin{array}{c}\text { Sari and } \\
\text { Karaipekli } \\
{[34]}\end{array}$ \\
\hline
\end{tabular}




\begin{tabular}{|c|c|c|c|c|c|c|c|c|c|c|c|}
\hline 4 & Erythritol & 117 & 119 & 339 & 305 & 1000 & - & - & $\begin{array}{l}\text { 1) Rheometric Scientific } \\
\text { Ltd.DSC } \\
\text { 2) Oven }\end{array}$ & No info & $\begin{array}{l}\text { Shukla et } \\
\text { al. [29] }\end{array}$ \\
\hline \multirow{3}{*}{5} & \multirow{3}{*}{$\begin{array}{c}\text { Lauric acid } \\
\left(\mathrm{C}_{11} \mathrm{H}_{23} \mathrm{COOH}\right)\end{array}$} & - & 43.5 & - & 169.3 & 3 & - & 168.8 & Perkin Elmer DSC 2 & No info & $\begin{array}{l}\text { Abhat and } \\
\text { Malatidis } \\
\text { [36] }\end{array}$ \\
\hline & & 42.6 & 41.3 & 176.6 & 156.6 & 1200 & - & - & $\begin{array}{l}\text { 1) General V4.1C DuPont } \\
2000 \text { DSC } \\
\text { 2) Thermostatic chamber } \\
\text { setup }\end{array}$ & $\begin{array}{l}\text { The heating rate in DSC was } 10 \\
{ }^{\circ} \mathrm{C} / \mathrm{min} \text { for all runs }\end{array}$ & Sari [33] \\
\hline & & 42.6 & $39.5-44.1$ & 211.6 & 132.8 & 910 & - & - & $\begin{array}{l}\text { 1) General V4.1C DuPont } \\
2000 \text { DSC } \\
\text { 2) Thermostatic chamber } \\
\text { setup }\end{array}$ & $\begin{array}{l}\text { The heating rate in DSC was } 10 \\
{ }^{\circ} \mathrm{C} / \mathrm{min} \text { for all runs }\end{array}$ & $\begin{array}{c}\text { Sari and } \\
\text { Kaygusuz } \\
{[40]}\end{array}$ \\
\hline 6 & Methyl palmitate & 29 & - & 215 & - & 50 & 214 & - & Perkin Elmer DSC - 4 & $\begin{array}{l}\text { The mean value of at least three } \\
\text { samples, recorded by DSC at a } \\
\text { heat } / \text { cool rate of } 5^{\circ} \mathrm{C} / \mathrm{min} \text {, was } \\
\text { taken }\end{array}$ & $\begin{array}{l}\text { Nikolic et } \\
\text { al. [39] }\end{array}$ \\
\hline 7 & Methyl stearate & 37.8 & - & 240 & - & 50 & 237 & - & Perkin Elmer DSC - 4 & $\begin{array}{l}\text { The mean value of at least three } \\
\text { samples, recorded by DSC at a } \\
\text { heat } / \text { cool rate of } 5^{\circ} \mathrm{C} / \mathrm{min} \text {, was } \\
\text { taken }\end{array}$ & $\begin{array}{l}\text { Nikolic et } \\
\text { al. [39] }\end{array}$ \\
\hline \multirow[t]{2}{*}{8} & \multirow[t]{2}{*}{$\begin{array}{c}\text { Myristic acid } \\
\left(\mathrm{C}_{13} \mathrm{H}_{27} \mathrm{COOH}\right)\end{array}$} & 50.4 & 49.8 & 189.4 & 163.5 & 450 & - & - & $\begin{array}{l}\text { 1) Perkin Elmer DSC } 2 \\
\text { 2) Two thermostatic baths } \\
\text { setup }\end{array}$ & $\begin{array}{l}\text { The heating rate in DSC was } 10 \\
{ }^{\circ} \mathrm{C} / \mathrm{min} \text {, with a heating range of } \\
10 \mathrm{mcal} / \mathrm{s} \text { and a scanning range } \\
\text { of } 290-390 \mathrm{~K}\end{array}$ & $\begin{array}{l}\text { Hasan and } \\
\text { Sayigh [37] }\end{array}$ \\
\hline & & 52.99 & 46.21 & 181.0 & 159.1 & 1200 & - & - & 1) General V4.1C DuPont & The heating rate in DSC was 10 & Sari [33] \\
\hline
\end{tabular}




\begin{tabular}{|c|c|c|c|c|c|c|c|c|c|c|c|}
\hline & & & & & & & & & $\begin{array}{c}2000 \text { DSC } \\
\text { 2) Thermostatic chamber } \\
\text { setup }\end{array}$ & ${ }^{\circ} \mathrm{C} / \mathrm{min}$ for all runs & \\
\hline & & 53.8 & $45.3-52.2$ & 192.0 & 159.1 & 910 & - & - & $\begin{array}{l}\text { 1) General V4.1C DuPont } \\
2000 \text { DSC } \\
\text { 2) Thermostatic chamber } \\
\text { setup }\end{array}$ & $\begin{array}{l}\text { The heating rate in DSC was } 10 \\
{ }^{\circ} \mathrm{C} / \mathrm{min} \text { for all runs }\end{array}$ & $\begin{array}{c}\text { Sari and } \\
\text { Kaygusuz } \\
{[40]}\end{array}$ \\
\hline \multirow{4}{*}{9} & \multirow{4}{*}{$\begin{array}{c}\text { Palmitic acid } \\
\left(\mathrm{C}_{15} \mathrm{H}_{31} \mathrm{COOH}\right)\end{array}$} & - & 61.2 & - & 196.1 & 3 & - & 197 & Perkin Elmer DSC 2 & No info & $\begin{array}{c}\text { Abhat and } \\
\text { Malatidis } \\
{[36]}\end{array}$ \\
\hline & & 57.8 & 57.7 & 201.2 & 184.4 & 450 & - & - & $\begin{array}{l}\text { 1) Perkin Elmer DSC } 2 \\
\text { 2) Two thermostatic baths } \\
\text { setup }\end{array}$ & $\begin{array}{l}\text { The heating rate in DSC was } 10 \\
{ }^{\circ} \mathrm{C} / \mathrm{min} \text {, with a heating range of } \\
10 \mathrm{mcal} / \mathrm{s} \text { and a scanning range } \\
\text { of } 290-390 \mathrm{~K}\end{array}$ & $\begin{array}{l}\text { Hasan and } \\
\text { Sayigh [37] }\end{array}$ \\
\hline & & 61.31 & 55.47 & 197.9 & 172.4 & 1200 & - & - & $\begin{array}{l}\text { 1) General V4.1C DuPont } \\
\qquad 2000 \text { DSC } \\
\text { 2) Thermostatic chamber } \\
\text { setup }\end{array}$ & $\begin{array}{l}\text { The heating rate in DSC was } \\
10^{\circ} \mathrm{C} / \mathrm{min}\end{array}$ & Sari [33] \\
\hline & & 60.9 & $55.5-62.2$ & 197.9 & 162.9 & 910 & - & - & $\begin{array}{l}\text { 1) General V4.1C DuPont } \\
2000 \text { DSC } \\
\text { 2) Thermostatic chamber } \\
\text { setup }\end{array}$ & $\begin{array}{l}\text { The heating rate In DSC was } 10 \\
{ }^{\circ} \mathrm{C} / \mathrm{min} \text { for all runs }\end{array}$ & $\begin{array}{c}\text { Sari and } \\
\text { Kaygusuz } \\
{[40]}\end{array}$ \\
\hline 10 & $\begin{array}{l}\text { Palmitic acid }(80 \\
w t \%)+ \text { expanded } \\
\text { graphite }(20 w t \%)\end{array}$ & 60.88 & 60.78 & 148.36 & 140.38 & 3000 & 149.66 & 139.97 & $\begin{array}{l}\text { 1) Perkin Elmer-Diamond } \\
\text { DSC } \\
\text { 2) Thermal cycler BIOER } \\
\text { TC- } 25 / \mathrm{H} \text { model }\end{array}$ & $\begin{array}{l}\text { The heating rate in DSC was } 5 \\
{ }^{\circ} \mathrm{C} / \text { min in a purified argon } \\
\text { atmosphere }\end{array}$ & $\begin{array}{c}\text { Sari and } \\
\text { Karaipekli } \\
\text { [41] }\end{array}$ \\
\hline
\end{tabular}




\begin{tabular}{|c|c|c|c|c|c|c|c|c|c|c|c|}
\hline \multirow{5}{*}{11} & \multirow{5}{*}{$\begin{array}{c}\text { Stearic acid } \\
\left(\mathrm{C}_{17} \mathrm{H}_{35} \mathrm{COOH}\right)\end{array}$} & 65.2 & 65.9 & 209.9 & 185.3 & 450 & - & - & $\begin{array}{l}\text { 1) Two thermostatic baths } \\
\text { setup } \\
\text { 2) Perkin Elmer DSC II }\end{array}$ & $\begin{array}{l}\text { The heating rate in DSC was } 10 \\
{ }^{\circ} \mathrm{C} / \mathrm{min} \text {, with a heating range of } \\
10 \mathrm{mcal} / \mathrm{s} \text { and a scanning range } \\
\text { of } 290-390 \mathrm{~K} \text {. }\end{array}$ & $\begin{array}{l}\text { Hasan and } \\
\text { Sayigh [37] }\end{array}$ \\
\hline & & 62.59 & 63 & 154.63 & 159 & 300 & - & - & $\begin{array}{l}\text { 1) Rheometric Scientific Ltd. } \\
\qquad \text { DSC } \\
\text { 2) Electric hot plate setup }\end{array}$ & $\begin{array}{l}\text { Isothermal-ramp-isothermal } \\
\text { method was used in DSC }\end{array}$ & $\begin{array}{c}\text { Sharma et } \\
\text { al. [26] }\end{array}$ \\
\hline & & 54.7 & 46.83 & 159.3 & 157.7 & 1200 & - & - & $\begin{array}{l}\text { 1) General V4.1C DuPont } \\
2000 \text { DSC } \\
\text { 2) Thermostatic chamber } \\
\text { setup }\end{array}$ & $\begin{array}{l}\text { The heating rate in DSC was } 10 \\
{ }^{\circ} \mathrm{C} / \mathrm{min} \text { for all runs }\end{array}$ & Sari [33] \\
\hline & & 53.8 & $46.9-50.2$ & 174.6 & 118.9 & 910 & - & - & $\begin{array}{l}\text { 1) General V4.1C DuPont } \\
2000 \text { DSC } \\
\text { 2) Thermostatic chamber } \\
\text { setup }\end{array}$ & $\begin{array}{l}\text { The heating rate in DSC was } 10 \\
{ }^{\circ} \mathrm{C} / \mathrm{min} \text { for all runs }\end{array}$ & $\begin{array}{c}\text { Sari and } \\
\text { Kaygusuz } \\
{[40]}\end{array}$ \\
\hline & & 63 & 64 & 155 & 123 & 1500 & - & - & $\begin{array}{l}\text { 1) Rheometric Scientific Ltd. } \\
\qquad \text { DSC } \\
\text { 2) Electric hot plate setup }\end{array}$ & $\begin{array}{l}\text { Isothermal-ramp-isothermal } \\
\text { method was used in DSC }\end{array}$ & $\begin{array}{c}\text { Sharma et } \\
\text { al. [27] }\end{array}$ \\
\hline 12 & Urea & 133 & 85.64 & 239.70 & 97.91 & 50 & & & $\begin{array}{l}\text { 1) Rheometric Scientific Ltd. } \\
\qquad \text { DSC } \\
\text { 2) Electric hot plate setup }\end{array}$ & Heating at constant rate in DSC & $\begin{array}{c}\text { Sharma et } \\
\text { al. [38] }\end{array}$ \\
\hline 13 & D-mannitol 99\% & 150.96 & 131.92 & 234.35 & 99.48 & 50 & 224.55 & 109.5 & Q200 TA Instruments DSC & $\begin{array}{l}\text { An isothermal-ramp-isothermal } \\
\text { method with a heating rate of } \\
10 \mathrm{~K} / \mathrm{min} \text { was used in DSC to } \\
\text { cycle the samples under a } \\
\text { nitrogen flow of } 50 \mathrm{ml} / \mathrm{min} .40 \\
\mu 1 \text { Tzero aluminium hermetic }\end{array}$ & $\begin{array}{l}\text { Solé et al. } \\
\qquad[11]\end{array}$ \\
\hline
\end{tabular}




\begin{tabular}{|c|c|c|c|c|c|c|c|c|c|c|c|}
\hline & & & & & & & & & & $\begin{array}{l}\text { crucibles were used to contain } \\
\text { the samples. } \\
\text { The runs in which the } \\
\text { thermophysical properties were } \\
\text { measured were done at } 1 \mathrm{~K} / \mathrm{min} \\
\text { heating rate }\end{array}$ & \\
\hline 14 & Myo-inositol 98\% & 216.29 & 221.22 & 185.25 & 165.02 & 100 & 206.55 & 176.4 & Q200 TA Instruments DSC & $\begin{array}{l}\text { An isothermal-ramp-isothermal } \\
\text { method with a heating rate of } \\
10 \mathrm{~K} / \mathrm{min} \text { was used in DSC to } \\
\text { cycle the samples under a } \\
\text { nitrogen flow of } 50 \mathrm{ml} / \mathrm{min} .40 \\
\mu 1 \text { Tzero aluminium hermetic } \\
\text { crucibles were used to contain } \\
\text { the samples. } \\
\text { The runs in which the } \\
\text { thermophysical properties were } \\
\text { measured were done at } 1 \mathrm{~K} / \mathrm{min} \\
\text { heating rate }\end{array}$ & $\begin{array}{c}\text { Solé et al. } \\
\text { [11] }\end{array}$ \\
\hline 15 & Galacticol 97\% & 180.07 & - & 257.15 & - & 50 & 245.65 & - & Q200 TA Instruments DSC & $\begin{array}{l}\text { An isothermal-ramp-isothermal } \\
\text { method with a heating rate of } \\
10 \mathrm{~K} / \mathrm{min} \text { was used in DSC to } \\
\text { cycle the samples under a } \\
\text { nitrogen flow of } 50 \mathrm{ml} / \mathrm{min} .40 \\
\mu 1 \text { Tzero aluminium hermetic } \\
\text { crucibles were used to contain } \\
\text { the samples. } \\
\text { The runs in which the }\end{array}$ & $\begin{array}{c}\text { Solé et al. } \\
\text { [11] }\end{array}$ \\
\hline
\end{tabular}




\begin{tabular}{|l|l|l|l|l|l|l|l|l|l|}
\hline & & & & & & & & $\begin{array}{l}\text { thermophysical properties were } \\
\text { measured were done at 1 K/min } \\
\text { heating rate }\end{array}$ & \\
\hline
\end{tabular}


Table 5. Melting point and latent heat of thermal cycled organic eutectics

\begin{tabular}{|c|c|c|c|c|c|c|c|c|c|c|c|}
\hline \multirow[b]{2}{*}{$\begin{array}{l}\text { Sr. } \\
\mathbf{n}^{\mathbf{o}}\end{array}$} & \multirow[b]{2}{*}{ PCM } & \multicolumn{7}{|c|}{ Analytical parameters } & \multirow[b]{2}{*}{$\begin{array}{l}\text { 1) Thermal } \\
\text { equipment } \\
\text { 2) Cycling } \\
\text { equipment }\end{array}$} & \multirow[b]{2}{*}{ Analysis method } & \multirow[b]{2}{*}{ Reference } \\
\hline & & $\begin{array}{c}\text { Initial } \\
\text { melting } \\
\text { point } \\
\left({ }^{\circ} \mathrm{C}\right)\end{array}$ & $\begin{array}{c}\text { Final } \\
\text { melting } \\
\text { point }\left({ }^{\circ} \mathrm{C}\right)\end{array}$ & $\begin{array}{c}\text { Initial } \\
\text { latent } \\
\text { heat of } \\
\text { fusion } \\
(\mathrm{J} / \mathrm{g})\end{array}$ & $\begin{array}{c}\text { Final } \\
\text { latent } \\
\text { heat of } \\
\text { fusion } \\
(\mathrm{J} / \mathrm{g})\end{array}$ & $\begin{array}{l}\text { Thermal } \\
\text { cycles }\end{array}$ & $\begin{array}{c}\text { Initial } \\
\text { latent } \\
\text { heat of } \\
\text { crystalliz } \\
\text { ation } \\
(\mathrm{J} / \mathrm{g})\end{array}$ & $\begin{array}{c}\text { Final } \\
\text { latent } \\
\text { heat of } \\
\text { crystalliz } \\
\text { ation } \\
(\mathrm{J} / \mathrm{g})\end{array}$ & & & \\
\hline 1 & $\begin{array}{c}\text { Ammonium alum } \\
\left(\mathrm{NH}_{4} \mathrm{Al}\left(\mathrm{SO}_{4}\right)_{2}\right. \\
\left.12 \mathrm{H}_{2} \mathrm{O}\right)(15 \%)+ \\
\text { ammonium nitrate } \\
\left(\mathrm{NH}_{4} \mathrm{NO}_{3}\right)(85 \%)\end{array}$ & 58.5 & - & 208 & - & 1100 & - & - & $\begin{array}{l}\text { 1) DSC } \\
\text { 2) Calorimeter setup } \\
\text { using HDPE balls } \\
\text { and thermal bath }\end{array}$ & $5^{\circ} \mathrm{C} / \mathrm{min}$ heating rate in DSC & $\begin{array}{c}\text { Jotshi et al. } \\
\text { [49] }\end{array}$ \\
\hline \multirow[t]{2}{*}{2} & \multirow{2}{*}{$\begin{array}{c}\text { Capric acid }(65 \text { mol\%)+ } \\
\text { lauric acid }(35 \mathrm{~mol} \%)\end{array}$} & 13 & - & 116.76 & - & 120 & - & - & $\begin{array}{l}\text { 1) Mettler TA } 4000 \\
\text { DSC } \\
\text { 2) Thermostatic } \\
\text { water bath setup }\end{array}$ & - & $\begin{array}{l}\text { Dimaano } \\
\text { and Escoto } \\
\text { [50] }\end{array}$ \\
\hline & & 19.6 & - & 126.5 & - & 360 & - & - & $\begin{array}{l}\text { 1) DSC } \\
\text { 2) Electric hot plate } \\
\text { setup }\end{array}$ & - & $\begin{array}{l}\text { Shilei et al. } \\
\text { [53] }\end{array}$ \\
\hline 3 & $\begin{array}{c}\text { Capric acid }(73.5 \text { wt } \%) \\
+ \text { myristic acid }(26.5 \\
\text { wt } \%)\end{array}$ & 22.61 & - & 154.83 & - & 5000 & 156.42 & - & $\begin{array}{l}\text { 1) Setaram DSC } \\
131 \\
\text { 2) Two water baths } \\
\text { setup }\end{array}$ & $\begin{array}{l}\text { DSC } 5{ }^{\circ} \mathrm{C} / \mathrm{min} \text { constant heating rate, } \\
\text { in the temperature range of } 10-50 \\
{ }^{\circ} \mathrm{C} \text { and under a constant stream of } \\
\text { argon at atmospheric pressure }\end{array}$ & $\begin{array}{l}\text { Karaipekli } \\
\text { et al. [54] }\end{array}$ \\
\hline
\end{tabular}




\begin{tabular}{|c|c|c|c|c|c|c|c|c|c|c|c|}
\hline 4 & $\begin{array}{l}\text { Capric acid + }(83 \mathrm{wt} \%) \\
+ \text { stearic acid }(17 \mathrm{wt} \%)\end{array}$ & 24.7 & - & 178.6 & - & 5000 & - & - & $\begin{array}{l}\text { 1) Setaram DSC } \\
131 \\
\text { 2) Electric hot plate } \\
\text { setup }\end{array}$ & $\begin{array}{l}5{ }^{\circ} \mathrm{C} / \text { min heating rate was } \\
\text { conducted during all DSC } \\
\text { measurements }\end{array}$ & $\begin{array}{l}\text { Karaipekli } \\
\text { et al. [35] }\end{array}$ \\
\hline 5 & $\begin{array}{c}\text { Capric acid }(62 \mathrm{wt} \%)+ \\
\text { tetradecanol }(38 \mathrm{wt} \%)\end{array}$ & 18.90 & 18.12 & 100.50 & 96.30 & 1000 & 99.70 & 94.50 & $\begin{array}{l}\text { 1) } 204 \text { F1 Phoenix } \\
\text { NETZSCH DSC } \\
\text { 2) Two thermostatic } \\
\text { bath setup with } \\
\text { aluminium hollow } \\
\text { core slab }\end{array}$ & $\begin{array}{l}\text { DSC: analysis done at a heating rate } \\
\text { of } 1{ }^{\circ} \mathrm{C} / \text { min between } 5 \text { and } 50^{\circ} \mathrm{C} \text { in } \\
\text { purified nitrogen atmosphere }\end{array}$ & $\begin{array}{l}\text { Jingyu et } \\
\text { al. [63] }\end{array}$ \\
\hline 6 & $\begin{array}{l}\text { Caprylic acid (70 wt\%) } \\
+1 \text {-dodecanol (30 wt } \%)\end{array}$ & 6.52 & - & 171.06 & - & 120 & - & - & $\begin{array}{l}\text { 1) Perkin Elmer } \\
\text { Diamond DSC } \\
\text { 2) Thermostatic } \\
\text { bath chamber with } \\
\text { temperature } \\
\text { controller setup }\end{array}$ & $\begin{array}{l}\text { Thermostatic bath chamber: the } \\
\text { eutectic mixture was heated above } \\
\text { the melting temperature and then } \\
\text { cooled below the solidifying } \\
\text { temperature } \\
\text { DSC: nitrogen was used as the } \\
\text { purge gas at a heat flow rate of } 20 \\
\mathrm{ml} / \mathrm{min} \text {. Samples were subjected to } \\
\text { three consecutive cooling/heating } \\
\text { cycles between }-40 \text { and } 60^{\circ} \mathrm{C} \text { at a } \\
\text { scanning rate of } 10^{\circ} \mathrm{C} / \mathrm{min} \text {. The last } \\
\text { cooling and heating cycle was used } \\
\text { to determine the transition } \\
\text { temperatures and enthalpies }\end{array}$ & $\begin{array}{c}\text { Zuo et al. } \\
\text { [56] }\end{array}$ \\
\hline
\end{tabular}




\begin{tabular}{|c|c|c|c|c|c|c|c|c|c|c|c|}
\hline 7 & $\begin{array}{l}\text { Lauric acid }(66 \mathrm{wt} \%)+ \\
\text { myristic acid }(34 \mathrm{wt} \%)\end{array}$ & 34.2 & - & 166.8 & - & 1460 & - & - & $\begin{array}{l}\text { 1) DuPont } 2000 \\
\text { DSC } \\
\text { 2) Thermostatic } \\
\text { chamber with } \\
\text { temperature } \\
\text { controller }\end{array}$ & $\begin{array}{l}\text { Thermostatic chamber: A thermal } \\
\text { cycle consists of heating the PCM } \\
\text { above its melting temperature and } \\
\text { cooling the PCM at room } \\
\text { temperature } \\
\text { DSC: the thermal analyses were } \\
\text { carried out in the temperature range } \\
0-80^{\circ} \mathrm{C} \text { with a heating rate of } 5 \\
{ }^{\circ} \mathrm{C} / \text { min under a constant stream of } \\
\text { nitrogen at atmospheric pressure. }\end{array}$ & Sari [52] \\
\hline 8 & $\begin{array}{l}\text { Lauric acid }(69 \mathrm{wt} \%)+ \\
\text { palmitic acid }(31 \mathrm{wt} \%)\end{array}$ & 35.2 & 34.8 & 166.3 & 168.8 & 1460 & - & - & $\begin{array}{l}\text { 1) DuPont } 2000 \\
\text { DSC } \\
\text { 2) Thermostatic } \\
\text { chamber with } \\
\text { temperature } \\
\text { controller }\end{array}$ & $\begin{array}{l}\text { Thermostatic chamber: A thermal } \\
\text { cycle consists of heating the PCM } \\
\text { above its melting temperature and } \\
\text { cooling the PCM at room } \\
\text { temperature } \\
\text { DSC: the thermal analyses were } \\
\text { carried out in the temperature range } \\
0-80^{\circ} \mathrm{C} \text { with a heating rate of } 5 \\
{ }^{\circ} \mathrm{C} / \text { min under a constant stream of } \\
\text { nitrogen at atmospheric pressure }\end{array}$ & Sari [52] \\
\hline 9 & $\begin{array}{c}\text { Lauric acid }(75.5 \mathrm{wt} \%) \\
+ \text { stearic acid }(24.5 \\
\text { wt } \%)\end{array}$ & 37 & - & 182.7 & - & 360 & - & - & $\begin{array}{l}\text { 1) DuPont } 2000 \\
\text { DSC } \\
\text { 2) Thermostatic } \\
\text { chamber with }\end{array}$ & $\begin{array}{l}\text { Thermostatic chamber: A thermal } \\
\text { cycle consists of heating the PCM } \\
\text { above its melting temperature and } \\
\text { cooling the PCM at room } \\
\text { temperature }\end{array}$ & $\begin{array}{c}\text { Sari et al. } \\
\text { [51] }\end{array}$ \\
\hline
\end{tabular}




\begin{tabular}{|c|c|c|c|c|c|c|c|c|c|c|c|}
\hline & & & & & & & & & $\begin{array}{l}\text { temperature } \\
\text { controller }\end{array}$ & $\begin{array}{l}\text { DSC: the thermal analyses were } \\
\text { carried out in the temperature range } \\
0-80{ }^{\circ} \mathrm{C} \text { with a heating rate of } 5 \\
{ }^{\circ} \mathrm{C} / \text { min under a constant stream of } \\
\text { nitrogen at atmospheric pressure }\end{array}$ & \\
\hline 10 & $\begin{array}{l}\text { Lauric acid }(77.05 \mathrm{wt} \%) \\
+ \text { palmitic acid }(22.95 \\
\text { wt } \%)\end{array}$ & 33.09 & 32.92 & 150.6 & 165.69 & 100 & - & - & Perkin Elmer DSC7 & $\begin{array}{l}\text { DSC: scanning rate of } 3{ }^{\circ} \mathrm{C} / \mathrm{min} \text { in } \\
\text { the temperature range of } 30-70{ }^{\circ} \mathrm{C}\end{array}$ & $\begin{array}{l}\text { Zhang et } \\
\text { al. [32] }\end{array}$ \\
\hline 11 & $\begin{array}{l}\text { Methyl stearate ( } 86 \\
\qquad \mathrm{wt} \%)+ \text { methyl } \\
\text { palmitate (14 wt } \%)\end{array}$ & 23.9 & - & 220 & - & 50 & 220 & - & Perkin Elmer DSC4 & DSC: heat $/ \mathrm{cool}$ rate of $5^{\circ} \mathrm{C} / \mathrm{min}$ & $\begin{array}{l}\text { Nikolic et } \\
\text { al. [39] }\end{array}$ \\
\hline 12 & $\begin{array}{c}\text { Methyl stearate }(91 \\
\text { wt } \%)+ \text { cetyl palmitate } \\
(9 \mathrm{wt} \%)\end{array}$ & 28.2 & - & 189 & - & 50 & 185 & - & Perkin Elmer DSC4 & DSC: heat $/ \mathrm{cool}$ rate of $5^{\circ} \mathrm{C} / \mathrm{min}$ & $\begin{array}{l}\text { Nikolic et } \\
\text { al. [39] }\end{array}$ \\
\hline 13 & $\begin{array}{c}\text { Methyl stearate (91 } \\
\text { wt } \%)+ \text { cetyl stearate }(9 \\
\text { wt } \%)\end{array}$ & 22.2 & - & 180 & - & 50 & 175 & - & Perkin Elmer DSC4 & DSC: heat $/ \mathrm{cool}$ rate of $5^{\circ} \mathrm{C} / \mathrm{min}$ & $\begin{array}{l}\text { Nikolic et } \\
\text { al. [39] }\end{array}$ \\
\hline 14 & $\begin{array}{c}\text { Myristic acid }(58 \mathrm{wt} \%) \\
+ \text { palmitic acid }(42 \\
\text { wt } \%)\end{array}$ & 42.6 & - & 169.7 & - & 360 & - & - & $\begin{array}{l}\text { 1) DuPont } 2000 \\
\text { DSC } \\
\text { 2) Thermostatic } \\
\text { chamber with } \\
\text { temperature } \\
\text { controller }\end{array}$ & $\begin{array}{l}\text { Thermostatic chamber: A thermal } \\
\text { cycle consists of heating the PCM } \\
\text { above its melting temperature and } \\
\text { cooling the PCM at room } \\
\text { temperature } \\
\text { DSC: the thermal analyses were }\end{array}$ & $\begin{array}{c}\text { Sari et al. } \\
\text { [51] }\end{array}$ \\
\hline
\end{tabular}




\begin{tabular}{|c|c|c|c|c|c|c|c|c|c|c|c|}
\hline & & & & & & & & & & $\begin{array}{l}\text { carried out in the temperature range } \\
0-80{ }^{\circ} \mathrm{C} \text { with a heating rate of } 5 \\
{ }^{\circ} \mathrm{C} / \text { min under a constant stream of } \\
\text { nitrogen at atmospheric pressure }\end{array}$ & \\
\hline 15 & $\begin{array}{l}\text { Myristic acid (64 wt\%) } \\
+ \text { stearic acid (36 wt\%) }\end{array}$ & 44.1 & - & 182.4 & - & 1460 & - & - & $\begin{array}{l}\text { 1) DuPont } 2000 \\
\text { DSC } \\
\text { 2) Thermostatic } \\
\text { chamber with } \\
\text { temperature } \\
\text { controller }\end{array}$ & $\begin{array}{l}\text { Thermostatic chamber: A thermal } \\
\text { cycle consists of heating the PCM } \\
\text { above its melting temperature and } \\
\text { cooling the PCM at room } \\
\text { temperature } \\
\text { DSC: the thermal analyses were } \\
\text { carried out in the temperature range } \\
0-80^{\circ} \mathrm{C} \text { with a heating rate of } 5 \\
{ }^{\circ} \mathrm{C} / \text { min under a constant stream of } \\
\text { nitrogen at atmospheric pressure }\end{array}$ & Sari [52] \\
\hline 16 & Myristic acid + glycerol & 31.96 & 31.22 & 154.3 & 151.8 & 1000 & 148.8 & 153.4 & $\begin{array}{l}\text { 1) PerkinElmer } \\
\text { JADE DSC } \\
\text { 2) Thermostatic } \\
\text { chamber with } \\
\text { temperature } \\
\text { controller }\end{array}$ & $\begin{array}{l}\text { Thermostatic chamber: A thermal } \\
\text { cycle consists of heating the PCM } \\
\text { above its melting temperature and } \\
\text { cooling the PCM at room } \\
\text { temperature } \\
\text { DSC: the analyses were performed } \\
\text { at } 5^{\circ} \mathrm{C} / \text { min of constant heating rate, } \\
\text { in the temperature range } 5-80^{\circ} \mathrm{C} \text {, } \\
\text { under a constant stream of argon at } \\
\text { atmospheric pressure }\end{array}$ & $\begin{array}{c}\text { Sari et al. } \\
\quad[55]\end{array}$ \\
\hline
\end{tabular}




\begin{tabular}{|c|c|c|c|c|c|c|c|c|c|c|c|}
\hline 17 & $\begin{array}{c}\text { Palmitic acid (64.2 } \\
\mathrm{wt} \%)+ \text { stearic acid } \\
(35.8 \mathrm{wt} \%)\end{array}$ & 52.3 & - & 181.7 & - & 360 & - & - & $\begin{array}{l}\text { 1) DuPont } 2000 \\
\text { DSC } \\
\text { 2) Thermostatic } \\
\text { chamber with } \\
\text { temperature } \\
\text { controller }\end{array}$ & $\begin{array}{l}\text { Thermostatic chamber: A thermal } \\
\text { cycle consists of heating the PCM } \\
\text { above its melting temperature and } \\
\text { cooling the PCM at room } \\
\text { temperature } \\
\text { DSC: the thermal analyses were } \\
\text { carried out in the temperature range } \\
0-80^{\circ} \mathrm{C} \text { with a heating rate of } 5 \\
{ }^{\circ} \mathrm{C} / \text { min under a constant stream of } \\
\text { nitrogen at atmospheric pressure }\end{array}$ & $\begin{array}{c}\text { Sari et al } \\
\text { [51] }\end{array}$ \\
\hline 18 & Palmitic acid + glycerol & 58.50 & 57.45 & 185.9 & 175.8 & 1000 & 151.7 & 147.5 & $\begin{array}{l}\text { 1) PerkinElmer } \\
\text { JADE DSC } \\
\text { 2) Thermostatic } \\
\text { chamber with } \\
\text { temperature } \\
\text { controller }\end{array}$ & $\begin{array}{l}\text { Thermostatic chamber: A thermal } \\
\text { cycle consists of heating the PCM } \\
\text { above its melting temperature and } \\
\text { cooling the PCM at room } \\
\text { temperature } \\
\text { DSC: the analyses were performed } \\
\text { at } 5^{\circ} \mathrm{C} / \text { min of constant heating rate, } \\
\text { in the temperature range } 5-80^{\circ} \mathrm{C} \text {, } \\
\text { under a constant stream of argon at } \\
\text { atmospheric pressure }\end{array}$ & $\begin{array}{c}\text { Sari et al } \\
{[55]}\end{array}$ \\
\hline 19 & Stearic acid + glycerol & 63.45 & 62.83 & 149.4 & 152.8 & 1000 & 64.58 & 60.06 & $\begin{array}{l}\text { 1) PerkinElmer } \\
\text { JADE DSC } \\
\text { 2) Thermostatic } \\
\text { chamber with }\end{array}$ & $\begin{array}{l}\text { Thermostatic chamber: A thermal } \\
\text { cycle consists of heating the PCM } \\
\text { above its melting temperature and } \\
\text { cooling the PCM at room } \\
\text { temperature }\end{array}$ & $\begin{array}{c}\text { Sari et al. } \\
\text { [55] }\end{array}$ \\
\hline
\end{tabular}




\begin{tabular}{|c|c|c|c|c|c|c|c|c|c|c|c|}
\hline & & & & & & & & & $\begin{array}{l}\text { temperature } \\
\text { controller }\end{array}$ & $\begin{array}{l}\text { DSC: the analyses were performed } \\
\text { at } 5^{\circ} \mathrm{C} / \text { min of constant heating rate, } \\
\text { in the temperature range } 5-80{ }^{\circ} \mathrm{C} \text {, } \\
\text { under a constant stream of argon at } \\
\text { atmospheric pressure }\end{array}$ & \\
\hline 20 & $\begin{array}{l}\text { Tetradodecanol }(53.60 \\
\mathrm{wt} \%)+ \text { lauric acid } \\
(46.40 \mathrm{wt} \%)\end{array}$ & 24.53 & 23.22 & 90.20 & 85.70 & 1000 & 88.70 & 85.10 & $\begin{array}{l}\text { 1) } 204 \text { F1 Phoenix } \\
\text { NETZSCH DSC } \\
\text { 2) Two thermostatic } \\
\text { bath setup with } \\
\text { aluminium hollow } \\
\text { core slab }\end{array}$ & $\begin{array}{l}\text { DSC: analysis done at a heating rate } \\
\text { of } 1{ }^{\circ} \mathrm{C} / \mathrm{min} \text { between } 5 \text { and } 50^{\circ} \mathrm{C} \text { in } \\
\text { purified nitrogen atmosphere }\end{array}$ & $\begin{array}{c}\text { Jingyu et } \\
\text { al. [63] }\end{array}$ \\
\hline 21 & $\begin{array}{l}\text { Tetradodecanol }(71.84 \\
\mathrm{wt} \%)+ \text { myristic acid } \\
(28.16 \mathrm{wt} \%)\end{array}$ & 33.15 & 32.65 & 128.60 & 123.50 & 1000 & 125.70 & 121.70 & $\begin{array}{l}\text { 1) } 204 \text { F1 Phoenix } \\
\text { NETZSCH DSC } \\
\text { 2) Two thermostatic } \\
\text { bath setup }\end{array}$ & $\begin{array}{l}\text { DSC: analysis done at a heating rate } \\
\text { of } 1{ }^{\circ} \mathrm{C} / \text { min between } 5 \text { and } 50^{\circ} \mathrm{C} \text { in } \\
\text { purified nitrogen atmosphere }\end{array}$ & $\begin{array}{c}\text { Jingyu et } \\
\text { al. [63] }\end{array}$ \\
\hline
\end{tabular}


Table 6. Melting point and latent heat of thermal cycled salt hydrates

\begin{tabular}{|c|c|c|c|c|c|c|c|c|c|c|c|}
\hline \multirow[b]{2}{*}{ Sr. $n^{\circ}$} & \multirow[b]{2}{*}{ PCM } & \multicolumn{7}{|c|}{ Analytical parameters } & \multirow[b]{2}{*}{$\begin{array}{l}\text { 1) Thermal equipment } \\
\text { 2) Cycling equipment }\end{array}$} & \multirow[b]{2}{*}{ Analysis method } & \multirow[b]{2}{*}{ Reference } \\
\hline & & $\begin{array}{c}\text { Initial } \\
\text { melting } \\
\text { point } \\
\left({ }^{\circ} \mathrm{C}\right)\end{array}$ & $\begin{array}{c}\text { Final } \\
\text { melting } \\
\text { point } \\
\left({ }^{\circ} \mathrm{C}\right)\end{array}$ & $\begin{array}{c}\text { Initial } \\
\text { latent heat } \\
\text { of fusion } \\
(\mathrm{J} / \mathrm{g})\end{array}$ & $\begin{array}{c}\text { Final latent } \\
\text { heat of } \\
\text { fusion }(\mathrm{J} / \mathrm{g})\end{array}$ & $\begin{array}{c}\text { Thermal } \\
\text { cycles }\end{array}$ & $\begin{array}{c}\text { Initial } \\
\text { latent } \\
\text { heat of } \\
\text { crystalliz } \\
\text { ation } \\
\text { (J/g) }\end{array}$ & $\begin{array}{c}\text { Final } \\
\text { latent } \\
\text { heat of } \\
\text { crystalliz } \\
\text { ation } \\
(\mathrm{J} / \mathrm{g})\end{array}$ & & & \\
\hline \multirow{5}{*}{1} & \multirow{5}{*}{$\begin{array}{l}\text { Calcium chloride } \\
\text { hexahydrate } \\
\left(\mathrm{CaCl}_{2} \cdot 6 \mathrm{H}_{2} \mathrm{O}\right)\end{array}$} & 29.8 & - & 190.8 & - & 1000 & - & - & $\begin{array}{l}\text { 1) Perkin Elmer DSC } 2 \\
\text { 2) Heat Exchange by } \\
\text { water circulation in a } \\
\text { two tube setup }\end{array}$ & No info & $\begin{array}{c}\text { Kimura and } \\
\text { Kai [60] }\end{array}$ \\
\hline & & 28 & - & 86 & - & 1000 & 71 & - & $\begin{array}{l}\text { 1) Mettler DSC } \\
\text { 2) Water bath setup }\end{array}$ & No info & $\begin{array}{c}\text { Fellchenfeld } \\
\text { et al. [44] }\end{array}$ \\
\hline & & 27 & - & - & - & 5650 & - & - & Thermostatic chamber & $\begin{array}{l}\text { Stainless steel capsules were } \\
\text { filled with } 50 \mathrm{~g} \text { of samples } \\
\text { and introduced in a } \\
\text { thermostatic chamber where } \\
\text { they were cycled and from } \\
\text { where all data was logged }\end{array}$ & Porosini [45] \\
\hline & & 23.26 & 23.26 & 125.4 & 125.4 & 1000 & - & - & $\begin{array}{c}\text { TA Instruments DSC } \\
\text { Q-100 }\end{array}$ & $\begin{array}{l}\text { Cycling with DSC at a } \\
\text { constant rate of } 7{ }^{\circ} \mathrm{C} / \mathrm{min} \\
\text { between }-10 \text { and } 60^{\circ} \mathrm{C}\end{array}$ & $\begin{array}{c}\text { Tyagi et al. } \\
\text { [48] }\end{array}$ \\
\hline & & - & 29 & - & 160 & 18 & - & - & Perkin Elmer DSC 2 & No info & Abhat and \\
\hline
\end{tabular}




\begin{tabular}{|c|c|c|c|c|c|c|c|c|c|c|c|}
\hline & & & & & & & & & & & $\begin{array}{c}\text { Malatidis } \\
\text { [36] }\end{array}$ \\
\hline \multirow[b]{2}{*}{2} & \multirow[b]{2}{*}{$\begin{array}{c}\text { Glauber's salt } \\
\left(\mathrm{Na}_{2} \mathrm{SO}_{4} \cdot 10 \mathrm{H}_{2} \mathrm{O}\right)\end{array}$} & 32.4 & - & 238 & - & 320 & - & - & $\begin{array}{l}\text { 1) Calorimeter } \\
\text { 2) Thermal cycling } \\
\text { chamber }\end{array}$ & $\begin{array}{l}\text { No DSC used. The paper } \\
\text { explains the calorimetric } \\
\text { measure method }\end{array}$ & Marks [59] \\
\hline & & 32 & - & - & - & 5650 & - & - & Thermostatic chamber & $\begin{array}{l}\text { Stainless steel capsules were } \\
\text { filled with } 50 \mathrm{~g} \text { of samples } \\
\text { and introduced in a } \\
\text { thermostatic chamber where } \\
\text { they were cycled and from } \\
\text { where all data was logged }\end{array}$ & Porosini [45] \\
\hline \multirow[t]{2}{*}{3} & \multirow{2}{*}{$\begin{array}{l}\text { Magnesium chloride } \\
\text { hexahydrate }\left(\mathrm{MgCl}_{2} \text {. }\right. \\
\left.6 \mathrm{H}_{2} \mathrm{O}\right)\end{array}$} & 111.5 & 124.12 & 155.11 & 85 & 500 & - & - & $\begin{array}{l}\text { 1) Shimadzu DSC-60 } \\
\text { 2) Heraeus D-6450 } \\
\text { Electric Oven }\end{array}$ & $\begin{array}{l}\text { The samples were cycled in } \\
\text { the DSC at } 10 \mathrm{~K} / \text { min between } \\
\text { ambient temperature and } 200 \\
{ }^{\circ} \mathrm{C} \text {. The analysis was carried } \\
\text { out under a constant nitrogen } \\
\text { stream of } 50 \mathrm{mil} / \mathrm{min} \text {. The } \\
\text { samples are heated at a } \\
\text { constant rate }\end{array}$ & $\begin{array}{c}\text { El-Sebaii et } \\
\text { al. [42] }\end{array}$ \\
\hline & & 110.8 & 115.39 & 138 & 130.28 & 1002 & - & - & $\begin{array}{l}\text { 1) Shimadzu DSC-60 } \\
\text { 2) Heraeus D-6450 } \\
\text { Electric Oven }\end{array}$ & $\begin{array}{l}\text { The samples were cycled in } \\
\text { the DSC at } 10 \mathrm{~K} / \text { min between } \\
\text { ambient temperature and } 200 \\
{ }^{\circ} \mathrm{C} \text {. The analysis was carried } \\
\text { out under a constant nitrogen } \\
\text { stream of } 50 \mathrm{mil} / \mathrm{min} \text {. The } \\
\text { samples are heated at a }\end{array}$ & $\begin{array}{c}\text { El-Sebaii et } \\
\text { al. [58] }\end{array}$ \\
\hline
\end{tabular}




\begin{tabular}{|c|c|c|c|c|c|c|c|c|c|c|c|}
\hline & & & & & & & & & & constant rate & \\
\hline 4 & $\begin{array}{c}\mathrm{Na}_{2} \mathrm{SO}_{4} \cdot 1 / 2 \mathrm{NaCl} \cdot \\
10 \mathrm{H}_{2} \mathrm{O}\end{array}$ & 20 & - & - & - & 5650 & - & - & Thermostatic chamber & $\begin{array}{l}\text { Stainless steel capsules were } \\
\text { filled with } 50 \mathrm{~g} \text { of samples } \\
\text { and introduced in a } \\
\text { thermostatic chamber where } \\
\text { they were cycled and from } \\
\text { where all data was logged }\end{array}$ & Porosini [45] \\
\hline 5 & $\mathrm{NaOH} \cdot 3,5 \mathrm{H}_{2} \mathrm{O}$ & 15 & - & - & - & 5650 & - & - & Thermostatic chamber & $\begin{array}{l}\text { Stainless steel capsules were } \\
\text { filled with } 50 \mathrm{~g} \text { of samples } \\
\text { and introduced in a } \\
\text { thermostatic chamber where } \\
\text { they were cycled and from } \\
\text { where all data was logged }\end{array}$ & Porosini [45] \\
\hline 6 & $\begin{array}{c}\text { Sodium acetate } \\
\text { trihydrate }\left(\mathrm{NaCH}_{3} \mathrm{COO}\right. \\
\left.\cdot 3 \mathrm{H}_{2} \mathrm{O}\right)\end{array}$ & 58 & - & 230 & - & 500 & - & - & $\begin{array}{l}\text { 1) Calorimeter } \\
\text { 2) Thermal bath }\end{array}$ & $\begin{array}{l}\text { The stainless steel vessel that } \\
\text { contained the sample was put } \\
\text { into a water bath a } \\
\text { consecutively heated and } \\
\text { cooled at a rate of } 5^{\circ} \mathrm{C} / \mathrm{min} \text {. } \\
\text { Calorimetric measurements } \\
\text { were performed to measure } \\
\text { the thermal properties. }\end{array}$ & $\begin{array}{l}\text { Wada et al. } \\
\text { [61] }\end{array}$ \\
\hline 7 & $\begin{array}{l}\text { Trichlorofluoromethane } \\
\text { heptadecahydrate } \\
\left(\mathrm{CCl}_{3} \mathrm{~F} \cdot 17 \mathrm{H}_{2} \mathrm{O}\right)\end{array}$ & 8.5 & - & 274 & - & 100 & - & - & $\begin{array}{l}\text { 1) Perkin Elmer DSC } 2 \\
\text { 2) Glass beaker with } \\
\text { water jacket }\end{array}$ & No info & $\begin{array}{c}\text { Kimura and } \\
\text { Kai [43] }\end{array}$ \\
\hline
\end{tabular}


Table 7. Melting point and latent heat of thermal cycled metallic alloys

\begin{tabular}{|c|c|c|c|c|c|c|c|c|c|c|c|}
\hline $\begin{array}{l}\text { Sr. } \\
n^{\circ}\end{array}$ & PCM & $\begin{array}{c}\text { Initial } \\
\text { melting } \\
\text { point } \\
\left({ }^{\circ} \mathrm{C}\right)\end{array}$ & $\begin{array}{c}\text { Final } \\
\text { melting } \\
\text { point }\left({ }^{\circ} \mathrm{C}\right)\end{array}$ & $\begin{array}{c}\text { Initial } \\
\text { latent } \\
\text { heat of } \\
\text { fusion } \\
(\mathrm{J} / \mathrm{g})\end{array}$ & $\begin{array}{c}\text { Final } \\
\text { latent } \\
\text { heat of } \\
\text { fusion } \\
(\mathrm{J} / \mathrm{g})\end{array}$ & $\begin{array}{c}\text { Thermal } \\
\text { cycles }\end{array}$ & $\begin{array}{c}\text { Initial } \\
\text { latent } \\
\text { heat of } \\
\text { crystalliz } \\
\text { ation } \\
(\mathrm{J} / \mathrm{g})\end{array}$ & $\begin{array}{c}\text { Final } \\
\text { latent } \\
\text { heat of } \\
\text { crystalliz } \\
\text { ation } \\
(\mathrm{J} / \mathrm{g})\end{array}$ & $\begin{array}{l}\text { 1) Thermal } \\
\text { equipment } \\
\text { 2) Cycling } \\
\text { equipment }\end{array}$ & Analysis method & Reference \\
\hline 1 & Al-34\%Mg-6\%Zn alloy & 450.31 & 447.25 & 329.1 & 292.96 & 1000 & - & - & $\begin{array}{l}\text { 1) Q10-V5.1- } \\
\text { Build191 DSC } \\
\text { 2) Thermostatic } \\
\text { chamber }\end{array}$ & $\begin{array}{l}\text { The DSC thermal analyses were } \\
\text { performed in the temperature range } \\
\text { of } 298-823 \mathrm{~K} \text { with a heating } \\
\text { rate of } 10 \mathrm{~K} / \mathrm{min} \text { and under } 80 \\
\mathrm{ml} / \mathrm{min} \text { of nitrogen at } \\
\text { atmospheric pressure }\end{array}$ & $\begin{array}{c}\text { Sun et al. } \\
\text { [57] }\end{array}$ \\
\hline
\end{tabular}


Table 8. Melting point and latent heat of thermal cycled inorganic eutectics

\begin{tabular}{|c|c|c|c|c|c|c|c|c|c|c|c|}
\hline \multirow[b]{2}{*}{$\begin{array}{l}\text { Sr. } \\
\text { no }^{\circ}\end{array}$} & \multirow[b]{2}{*}{ PCM } & \multicolumn{7}{|c|}{ Analytical parameters } & \multirow[b]{2}{*}{$\begin{array}{l}\text { 1) Thermal } \\
\text { equipment } \\
\text { 2) Cycling } \\
\text { equipment }\end{array}$} & \multirow[b]{2}{*}{ Analysis method } & \multirow[b]{2}{*}{ Reference } \\
\hline & & $\begin{array}{c}\text { Initial } \\
\text { melting } \\
\text { point } \\
\left({ }^{\circ} \mathrm{C}\right)\end{array}$ & $\begin{array}{c}\text { Final } \\
\text { melting } \\
\text { point }\left({ }^{\circ} \mathrm{C}\right)\end{array}$ & $\begin{array}{c}\text { Initial } \\
\text { latent } \\
\text { heat of } \\
\text { fusion } \\
(\mathrm{J} / \mathrm{g})\end{array}$ & $\begin{array}{c}\text { Final } \\
\text { latent } \\
\text { heat of } \\
\text { fusion } \\
(\mathrm{J} / \mathrm{g})\end{array}$ & $\begin{array}{c}\text { Thermal } \\
\text { cycles }\end{array}$ & $\begin{array}{c}\text { Initial } \\
\text { latent } \\
\text { heat of } \\
\text { crystalliz } \\
\text { ation } \\
\text { (J/g) }\end{array}$ & $\begin{array}{c}\text { Final } \\
\text { latent } \\
\text { heat of } \\
\text { crystalliz } \\
\text { ation } \\
\text { (J/g) }\end{array}$ & & & \\
\hline 1 & $\begin{array}{c}\mathrm{CaCl}_{2} \cdot 6 \mathrm{H}_{2} \mathrm{O}(80 \\
\mathrm{mol} \%)+\mathrm{CaBr}_{2} \cdot 6 \mathrm{H}_{2} \mathrm{O} \\
(20 \mathrm{~mol} \%)\end{array}$ & 20 & 21 & 117 & 120 & 1000 & - & - & Perkin Elmer DSC 2 & No info. & $\begin{array}{c}\text { Kimura } \\
\text { and Kai } \\
{[46]}\end{array}$ \\
\hline 2 & $\begin{array}{c}\mathrm{CaCl}_{2} \cdot 6 \mathrm{H}_{2} \mathrm{O}(93 \mathrm{wt} \%) \\
+\mathrm{Ca}\left(\mathrm{NO}_{3}\right)_{2} \cdot 4 \mathrm{H}_{2} \mathrm{O}(5 \\
\mathrm{wt} \%)+\mathrm{Mg}\left(\mathrm{NO}_{3}\right)_{2} \\
6 \mathrm{H}_{2} \mathrm{O}(2 \mathrm{wt} \%)\end{array}$ & 24 & 23 & 125 & 128 & 1000 & - & - & Perkin Elmer DSC 2 & No info. & $\begin{array}{c}\text { Kimura } \\
\text { and Kai } \\
{[46]}\end{array}$ \\
\hline 3 & $\begin{array}{c}\mathrm{CaCl}_{2} \cdot 6 \mathrm{H}_{2} \mathrm{O}(96 \mathrm{wt} \%) \\
+\mathrm{KNO}_{3}(2 \mathrm{wt} \%)+\mathrm{KBr} \\
(2 \mathrm{wt} \%)\end{array}$ & 23 & 23 & 138 & 139 & 1000 & - & - & Perkin Elmer DSC 2 & No info. & $\begin{array}{c}\text { Kimura } \\
\text { and Kai } \\
{[46]}\end{array}$ \\
\hline 4 & $\begin{array}{c}\mathrm{CaCl}_{2} \cdot 6 \mathrm{H}_{2} \mathrm{O}(96 \mathrm{wt} \%) \\
+\mathrm{NH}_{4} \mathrm{NO}_{3}(2 \mathrm{wt} \%)+ \\
\mathrm{NH}_{4} \mathrm{Br}(2 \mathrm{wt} \%)\end{array}$ & 20 & 19 & 141 & 141 & 1000 & - & - & Perkin Elmer DSC 2 & No info. & $\begin{array}{c}\text { Kimura } \\
\text { and Kai } \\
{[46]}\end{array}$ \\
\hline 5 & $\begin{array}{c}\mathrm{Mg}\left(\mathrm{NO}_{3}\right)_{2} \cdot 6 \mathrm{H}_{2} \mathrm{O}(93 \\
\mathrm{wt} \%)+\mathrm{MgCl}_{2} \cdot 6 \mathrm{H}_{2} \mathrm{O} \\
(7 \mathrm{wt} \%)\end{array}$ & 78 & - & 152.4 & - & 1000 & 77.2 & - & $\mathrm{DSC}$ & No info. & $\begin{array}{c}\text { Nagano et } \\
\text { al. [47] }\end{array}$ \\
\hline
\end{tabular}


Table 9. List of all the equipment and setups used for analysis and cycling

\begin{tabular}{|c|c|c|c|}
\hline Equipment & Model & Materials & Authors \\
\hline \multirow{4}{*}{ Setaram DSC } & \multirow{4}{*}{131} & Paraffin $70 \%+$ PP $30 \%$ & Alkan et al. [30] \\
\hline & & Capric acid (55wt\%) + expanded perlite (45 wt $\%)$ & Sari and Karaipekli [34] \\
\hline & & Capric acid (73.5 wt\%) + myristic acid (26.5 wt\%) & Karaipekli et al. [54] \\
\hline & & Capric acid + (83 wt $\%)+$ stearic acid $(17 \mathrm{wt} \%)$ & Karaipekli et al. [35] \\
\hline Mettler TA DSC & 4000 & Capric acid $(65 \mathrm{~mol} \%)+$ lauric acid $(35 \mathrm{~mol} \%)$ & Dimaano and Escoto [50] \\
\hline \multirow{3}{*}{ Mettler TA DSC } & \multirow{3}{*}{ - } & Paraffin $\left(\mathrm{C}_{22} \mathrm{H}_{44.1}\right)$ & Hadjieva et al. [28] \\
\hline & & Paraffin $\left(\mathrm{C}_{23} \mathrm{H}_{48.4}\right)$ & Hadjieva et al. [28] \\
\hline & & $\mathrm{CaCl}_{2} \cdot 6 \mathrm{H}_{2} \mathrm{O}$ & Fellchenfeld et al. [44] \\
\hline \multirow{10}{*}{ Rheometric Scientific Ltd. DSC } & \multirow{10}{*}{ - } & \multirow{2}{*}{ Paraffin wax 53} & Sharma et al. [26] \\
\hline & & & Sharma et al. [27] \\
\hline & & Paraffin wax 58-60 & Shukla et al. [29] \\
\hline & & Paraffin wax 60-62 & Shukla et al. [29] \\
\hline & & \multirow{2}{*}{ Acetamide } & Sharma et al. [26] \\
\hline & & & Sharma et al. [27] \\
\hline & & Erythritol & Shukla et al. [29] \\
\hline & & \multirow{2}{*}{ Stearic acid } & Sharma et al. [26] \\
\hline & & & Sharma et al. [27] \\
\hline & & Urea & Sharma et al. [38] \\
\hline \multirow{3}{*}{ Perkin Elmer DSC } & \multirow{3}{*}{ Diamond } & $\mathrm{C}_{17} \mathrm{H}_{36}$ & Sari et al. [31] \\
\hline & & Palmitic acid $(80 \mathrm{wt} \%)+$ expanded graphite $(20 \mathrm{wt} \%)$ & Sari and Karaipekli [41] \\
\hline & & Caprylic acid $(70 \mathrm{wt} \%)+1$-dodecanol (30 wt\%) & Zuo et al. [56] \\
\hline
\end{tabular}




\begin{tabular}{|c|c|c|c|}
\hline \multirow{3}{*}{ Perkin Elmer DSC } & \multirow{3}{*}{ Jade } & Myristic acid + glycerol & Sari et al. [55] \\
\hline & & Palmitic acid + glycerol & Sari et al. [55] \\
\hline & & Stearic acid + glycerol & Sari et al. [55] \\
\hline Perkin Elmer DSC & 7 & Lauric acid $(77.05 \mathrm{wt} \%)+$ palmitic acid $(22.95 \mathrm{wt} \%)$ & Zhang et al. [32] \\
\hline \multirow{5}{*}{ Perkin Elmer DSC } & \multirow{5}{*}{4} & Methyl palmitate & Nikolic et al. [39] \\
\hline & & Methyl stearate & Nikolic et al. [39] \\
\hline & & Methyl stearate $(86 \mathrm{wt} \%)+$ methyl palmitate (14 wt $\%)$ & Nikolic et al. [39] \\
\hline & & Methyl stearate $(91 \mathrm{wt} \%)+$ cetyl palmitate $(9 \mathrm{wt} \%)$ & Nikolic et al. [39] \\
\hline & & Methyl stearate (91 wt $\%)+$ cetyl stearate $(9 \mathrm{wt} \%)$ & Nikolic et al. [39] \\
\hline \multirow{7}{*}{ Perkin Elmer DSC } & \multirow{7}{*}{2} & Myristic acid & Hasan and Sayigh [37] \\
\hline & & Palmitic acid & Abhat and Malatidis [36] \\
\hline & & Stearic acid & Hasan and Sayigh [37] \\
\hline & & $\mathrm{CaCl}_{2} \cdot 6 \mathrm{H}_{2} \mathrm{O}$ & Abhat and Malatidis [36] \\
\hline & & $\mathrm{CCl}_{3} \mathrm{~F} \cdot 17 \mathrm{H}_{2} \mathrm{O}$ & Kimura and Kai [43] \\
\hline & & $\mathrm{CaCl}_{2} \cdot 6 \mathrm{H}_{2} \mathrm{O}$ compounds & Kimura and Kai [46] \\
\hline & & Lauric acid & Abhat and Malatidis [36] \\
\hline \multirow{2}{*}{ Shimadzu DSC } & \multirow{2}{*}{60} & Acetanilide & El-Sebaii et al. [42] \\
\hline & & $\mathrm{MgCl}_{2} \cdot 6 \mathrm{H}_{2} \mathrm{O}$ & El-Sebaii et al. [58] \\
\hline \multirow{5}{*}{ DuPont DSC } & \multirow{5}{*}{ General V4.1C 2000} & \multirow{2}{*}{ Lauric acid } & Sari [33] \\
\hline & & & Sari and Kaygusuz [40] \\
\hline & & \multirow{2}{*}{ Myristic acid } & Sari [33] \\
\hline & & & Sari and Kaygusuz [40] \\
\hline & & Palmitic acid & Sari [33] \\
\hline
\end{tabular}




\begin{tabular}{|c|c|c|c|}
\hline & & & Sari and Kaygusuz [40] \\
\hline & & \multirow{2}{*}{ Stearic acid } & Sari [33] \\
\hline & & & Sari and Kaygusuz [40] \\
\hline \multirow{6}{*}{ DuPont DSC } & \multirow{6}{*}{2000} & Lauric acid (66 wt\%) + myristic acid (34 wt $\%)$ & Sari [52] \\
\hline & & Lauric acid $(69 \mathrm{wt} \%)+$ palmitic acid $(31 \mathrm{wt} \%)$ & Sari [52] \\
\hline & & Lauric acid $(75.5 w t \%)+$ stearic acid $(24.5 w t \%)$ & Sari et al. [51] \\
\hline & & Myristic acid $(58 w t \%)+$ palmitic acid $(42 \mathrm{wt} \%)$ & Sari et al. [51] \\
\hline & & Myristic acid (64 wt\%) + stearic acid (36 wt\%) & Sari $[52]$ \\
\hline & & Palmitic acid $(64.2 \mathrm{wt} \%)+$ stearic acid $(35.8 \mathrm{wt} \%)$ & Sari et al. [51] \\
\hline \multirow{3}{*}{ TA Instruments DSC } & \multirow{3}{*}{ Q2000 } & D-mannitol 99\% & Solé et al. [51] \\
\hline & & Myo-inositol 98\% & Solé et al. [51] \\
\hline & & Galacticol 97\% & Solé et al. [51] \\
\hline \multirow{2}{*}{ Mettler Toledo DSC } & \multirow{2}{*}{$820 \mathrm{C}$} & Microencapsulated paraffin wax $53(0.1 \mathrm{~g}) /$ polyaniline $(0.9 \mathrm{~g})$ & Silakhori et al. [52] \\
\hline & & Microencapsulated paraffin wax $53(0.2 \mathrm{~g}) /$ polyaniline $(0.8 \mathrm{~g})$ & Silakhori et al. [52] \\
\hline TA Instruments DSC & Q100 & $\mathrm{CaCl}_{2} \cdot 6 \mathrm{H}_{2} \mathrm{O}$ & Tyagi et al. [48] \\
\hline Build DSC & Q10-V5.1 191 & Al-34\%Mg-6\%Zn alloy & Sun et al. [57] \\
\hline \multirow{3}{*}{ NETZSCH DSC } & \multirow{3}{*}{204 F1 Phoenix } & Capric acid $(62 w t \%)+$ tetradecanol $(38 w t \%)$ & Jingyu et al. [63] \\
\hline & & Tetradodecanol (53.60 wt\%) + lauric acid (46.40 wt\%) & Jingyu et al. [63] \\
\hline & & Tetradodecanol $(71.84 \mathrm{wt} \%)+$ myristic acid $(28.16 \mathrm{wt} \%)$ & Jingyu et al. [63] \\
\hline Thermal cycler BIOER & $\mathrm{TC}-25 / \mathrm{H}$ & Palmitic acid $(80 \mathrm{wt} \%)+$ expanded graphite $(20 \mathrm{wt} \%)$ & Sari and Karaipekli [41] \\
\hline Thermal cycling chamber & - & Glauber's salt & Marks [59] \\
\hline \multirow{2}{*}{ Thermostatic chamber setup } & \multirow{2}{*}{-} & \multirow{2}{*}{ Lauric acid } & Sari [33] \\
\hline & & & Sari and Kaygusuz [40] \\
\hline
\end{tabular}




\begin{tabular}{|c|c|c|c|}
\hline & & \multirow{2}{*}{ Myristic acid } & Sari [33] \\
\hline & & & Sari and Kaygusuz [40] \\
\hline & & \multirow{2}{*}{ Palmitic acid } & Sari [33] \\
\hline & & & Sari and Kaygusuz [40] \\
\hline & & \multirow{2}{*}{ Stearic acid } & Sari [33] \\
\hline & & & Sari and Kaygusuz [40] \\
\hline & & \multirow{2}{*}{$\mathrm{CaCl}_{2} \cdot 6 \mathrm{H}_{2} \mathrm{O}$} & Fellchenfeld et al. [44] \\
\hline & & & Porosini $[45]$ \\
\hline & & Glauber's salt & Porosini [45] \\
\hline & & $\mathrm{Na}_{2} \mathrm{SO}_{4} \cdot 1 / 2 \mathrm{NaCl} \cdot 10 \mathrm{H}_{2} \mathrm{O}$ & Porosini [45] \\
\hline & & $\mathrm{NaOH} \cdot 3,5 \mathrm{H}_{2} \mathrm{O}$ & Porosini $[45]$ \\
\hline & & Al-34\%Mg-6\%Zn alloy & Sun et al. [57] \\
\hline & & Caprylic acid $(70 w t \%)+1-$ dodecanol $(30 w t \%)$ & Zuo et al. [56] \\
\hline & & Lauric acid (66 wt\%) + myristic acid (34 wt\%) & Sari [52] \\
\hline & & Lauric acid $(69 \mathrm{wt} \%)+$ palmitic acid $(31 \mathrm{wt} \%)$ & Sari [52] \\
\hline & & Lauric acid $(75.5 w t \%)+$ stearic acid $(24.5 w t \%)$ & Sari et al. [51] \\
\hline & & Myristic acid $(58 w t \%)+$ palmitic acid $(42 w t \%)$ & Sari et al. [51] \\
\hline & & Myristic acid (64 wt\%) + stearic acid (36 wt\%) & Sari [52] \\
\hline & & Myristic acid + glycerol & Sari et al. [55] \\
\hline & & Palmitic acid $(64.2 \mathrm{wt} \%)+$ stearic acid $(35.8 \mathrm{wt} \%)$ & Sari et al. [51] \\
\hline & & Palmitic acid + glycerol & Sari et al. [55] \\
\hline & & Stearic acid + glycerol & Sari et al. [55] \\
\hline Thermal bath setup & - & Capric acid (65 mol\%)+ lauric acid (35 mol\%) & Dimaano and Escoto [50] \\
\hline
\end{tabular}




\begin{tabular}{|c|c|c|c|}
\hline & & $\mathrm{NaCH}_{3} \mathrm{COO} \cdot 3 \mathrm{H}_{2} \mathrm{O}$ & Wada et al. [61] \\
\hline & & Paraffin $\left(\mathrm{C}_{22} \mathrm{H}_{44.1}\right)$ & Hadjieva et al. [28] \\
\hline & & Paraffin $\left(\mathrm{C}_{23} \mathrm{H}_{48.4}\right)$ & Hadjieva et al. [28] \\
\hline & & Paraffin $(70 \mathrm{wt} \%)+\mathrm{PP}(30 \mathrm{wt} \%)$ & Alkan et al. [30] \\
\hline & & $\mathrm{C}_{17} \mathrm{H}_{36}$ & Sari et al. [31] \\
\hline \multirow{7}{*}{ Two thermostatic bath setup } & \multirow{7}{*}{-} & Myristic acid & Hasan and Sayigh [37] \\
\hline & & Palmitic acid & Hasan and Sayigh [37] \\
\hline & & Stearic acid & Hasan and Sayigh [37] \\
\hline & & Capric acid $(73.5 \mathrm{wt} \%)+$ myristic acid $(26.5 \mathrm{wt} \%)$ & Karaipekli et al. [54] \\
\hline & & Capric acid $(62 \mathrm{wt} \%)+$ tetradecanol $(38 \mathrm{wt} \%)$ & Jingyu et al. [63] \\
\hline & & Tetradodecanol (53.60 wt\%) + lauric acid (46.40 wt\%) & Jingyu et al. [63] \\
\hline & & Tetradodecanol $(71.84 \mathrm{wt} \%)+$ myristic acid $(28.16 \mathrm{wt} \%)$ & Jingyu et al. [63] \\
\hline Glass beaker with water jacket circulation & - & $\mathrm{CCl}_{3} \mathrm{~F} \cdot 17 \mathrm{H}_{2} \mathrm{O}$ & Kimura and Kai [43] \\
\hline \multirow{10}{*}{ Electric hot plate setup } & \multirow{10}{*}{-} & \multirow{2}{*}{ Paraffin wax 53} & Sharma et al. [26] \\
\hline & & & Sharma et al. [27] \\
\hline & & \multirow{2}{*}{ Acetamide } & Sharma et al. [26] \\
\hline & & & Sharma et al. [27] \\
\hline & & \multirow{2}{*}{ Stearic acid } & Sharma et al. [26] \\
\hline & & & Sharma et al. [27] \\
\hline & & Urea & Sharma et al. [38] \\
\hline & & Capric acid (65 mol\%)+ lauric acid (35 mol\%) & Shilei et al. [53] \\
\hline & & Capric acid $+(83 w t \%)+$ stearic acid $(17 w t \%)$ & Karaipekli et al. [35] \\
\hline & & Capric acid $(55 w t \%)+$ expanded perlite $(45 w t \%)$ & Sari and Karaipekli [34] \\
\hline
\end{tabular}




\begin{tabular}{|c|c|c|c|}
\hline Two tube with water circulation setup & - & $\mathrm{CaCl}_{2} \cdot 6 \mathrm{H}_{2} \mathrm{O}$ & Kimura and Kai [60] \\
\hline \multirow{2}{*}{ Thermal box with heater and cooler setup } & & Microencapsulated paraffin wax $53(0.1 \mathrm{~g}) /$ polyaniline $(0.9 \mathrm{~g})$ & Silakhori et al. [62] \\
\hline & & Microencapsulated paraffin wax $53(0.2 \mathrm{~g}) /$ polyaniline $(0.8 \mathrm{~g})$ & Silakhori et al. [62] \\
\hline \multirow{3}{*}{ Oven } & \multirow{3}{*}{ Non specified } & Paraffin wax 58-60 & Shukla et al. [29] \\
\hline & & Paraffin wax 60-62 & Shukla et al. [29] \\
\hline & & Erythritol & Shukla et al. [29] \\
\hline \multirow{2}{*}{ Oven } & \multirow{2}{*}{ Heraeus D-6450 } & \multirow{2}{*}{$\mathrm{MgCl}_{2} \cdot 6 \mathrm{H}_{2} \mathrm{O}$} & El-Sebaii et al. [42] \\
\hline & & & El-Sebaii et al. [58] \\
\hline Calorimeter + thermal bath & - & $\left(\mathrm{NH}_{4} \mathrm{Al}\left(\mathrm{SO}_{4}\right)_{2} \cdot 12 \mathrm{H}_{2} \mathrm{O}\right)(15 \%)+\left(\mathrm{NH}_{4} \mathrm{NO}_{3}\right)(85 \%)$ & Jotshi et al. [49] \\
\hline
\end{tabular}


Table 10. List of the different cycling methods used by the authors

\begin{tabular}{|c|c|c|c|c|}
\hline \multicolumn{2}{|c|}{ Cycling method } & Materials & Equipment & References \\
\hline \multirow{21}{*}{$\begin{array}{c}\text { Pyramid method } \\
\wedge\end{array}$} & \multirow{4}{*}{$\begin{array}{l}\text { Cool down in } \\
\text { refrigeration plant }\end{array}$} & Paraffin $(70 w t \%)+P P(30 w t \%)$ & Electric hot plate setup & Alkan et al. [30] \\
\hline & & $\mathrm{C}_{17} \mathrm{H}_{36}$ & Electric hot plate setup & Sari et al. [31] \\
\hline & & Capric acid $(55 \mathrm{wt} \%)+$ expanded perlite $(45 \mathrm{wt} \%)$ & Electric hot plate setup & Sari and Karaipekli [34] \\
\hline & & Capric acid (65 mol\%)+ lauric acid (35 mol\%) & Electric hot plate setup & Shilei et al. [53] \\
\hline & \multirow{17}{*}{$\begin{array}{c}\text { Cool down at room } \\
\text { temperature }\end{array}$} & \multirow{2}{*}{ Paraffin wax 53} & Electric hot plate setup & Sharma et al. [26] \\
\hline & & & Electric hot plate setup & Sharma et al. [27] \\
\hline & & \multirow{2}{*}{ Acetamide } & Electric hot plate setup & Sharma et al. [26] \\
\hline & & & Electric hot plate setup & Sharma et al. [27] \\
\hline & & Paraffin wax 58-60 & Oven & Shukla et al. [29] \\
\hline & & Paraffin wax 60-62 & Oven & Shukla et al. [29] \\
\hline & & Erythritol & Oven & Shukla et al. [29] \\
\hline & & \multirow{2}{*}{ Lauric acid } & Thermostatic chamber setup & Sari [33] \\
\hline & & & Thermostatic chamber setup & Sari and Kaygusuz [40] \\
\hline & & \multirow{2}{*}{ Myristic acid } & Thermostatic chamber setup & Sari [33] \\
\hline & & & Thermostatic chamber setup & Sari and Kaygusuz [40] \\
\hline & & \multirow{2}{*}{ Palmitic acid } & Thermostatic chamber setup & Sari [33] \\
\hline & & & Thermostatic chamber setup & Sari and Kaygusuz [40] \\
\hline & & \multirow{4}{*}{ Stearic acid } & Electric hot plate setup & Sharma et al. [26] \\
\hline & & & Thermostatic chamber setup & Sari [33] \\
\hline & & & Thermostatic chamber setup & Sari and Kaygusuz [40] \\
\hline & & & Electric hot plate setup & Sharma et al. [27] \\
\hline
\end{tabular}




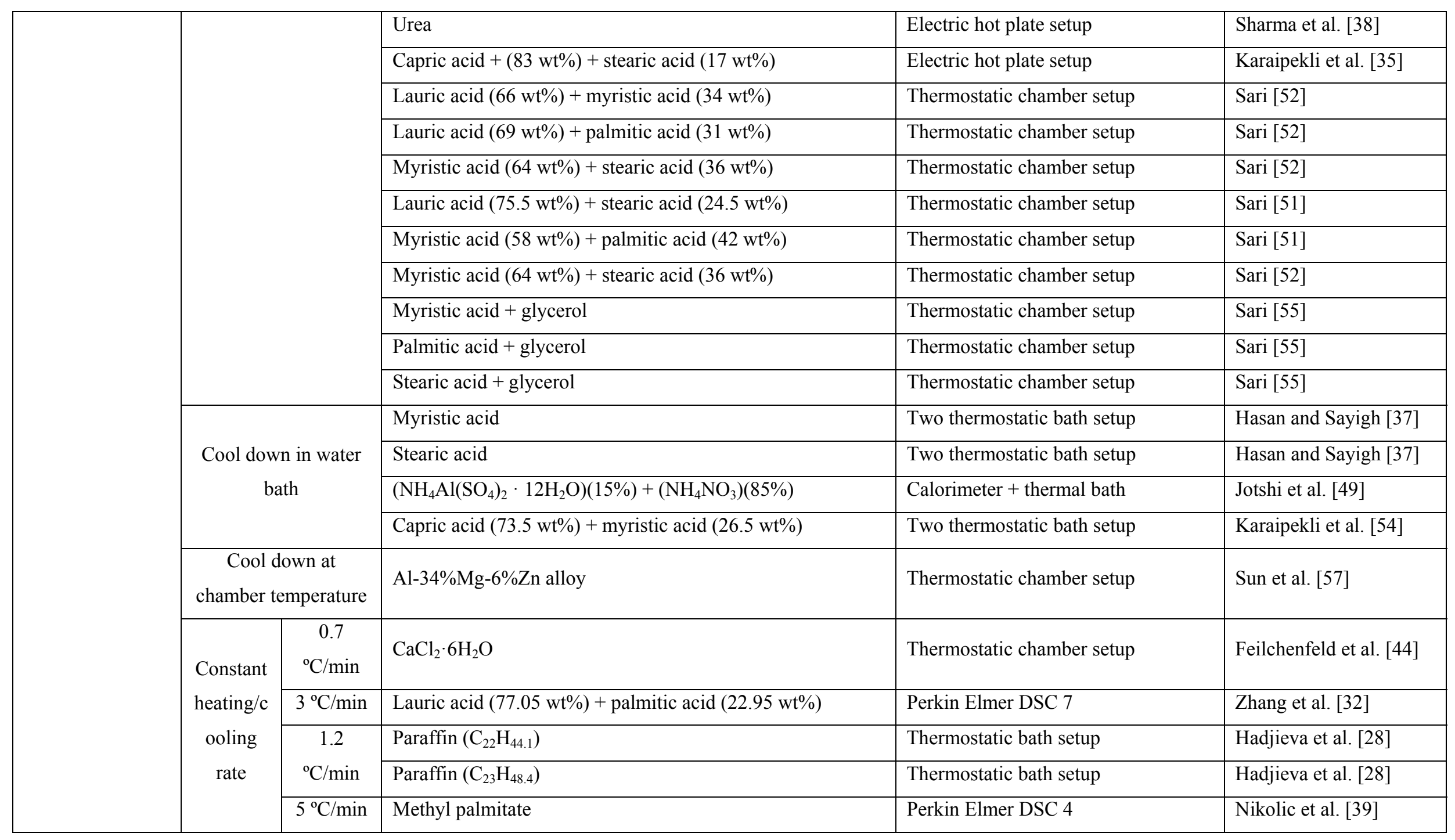




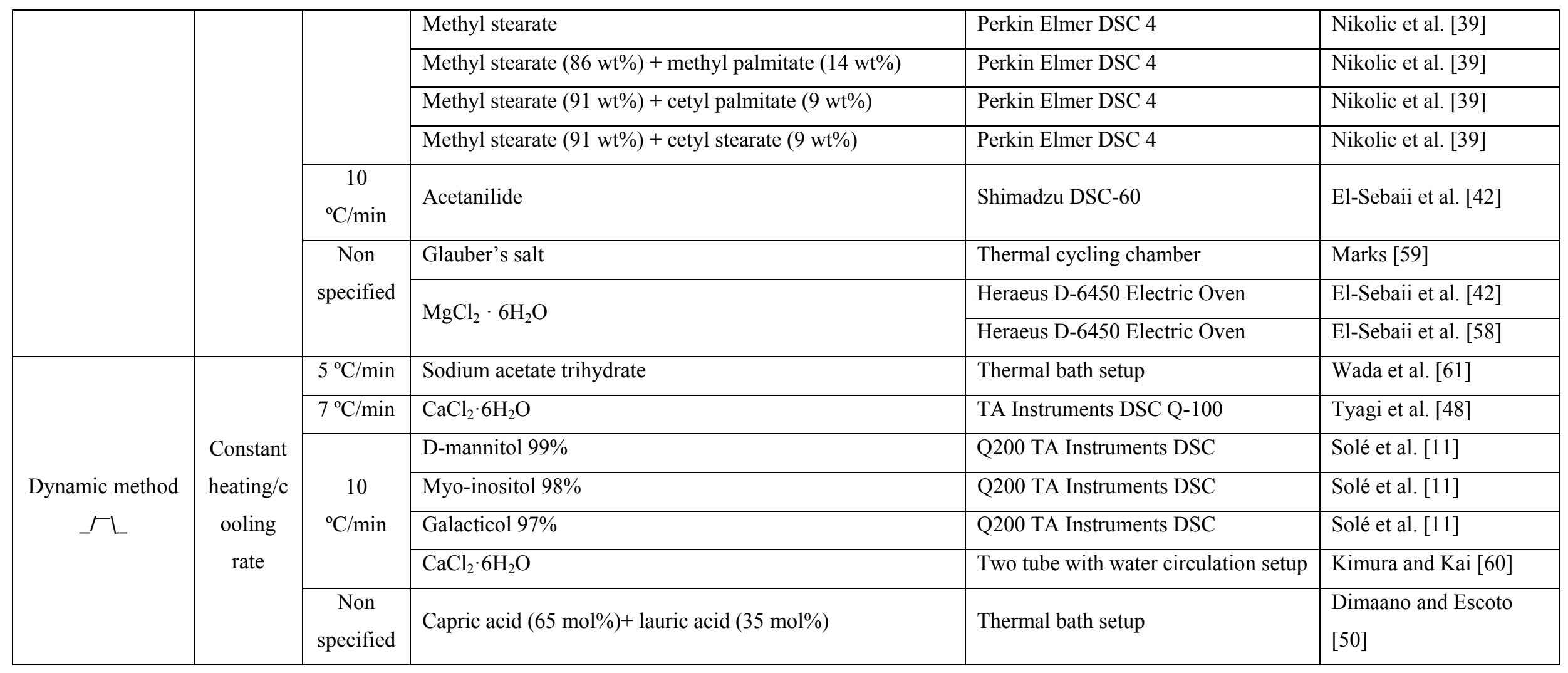


Table 11. List of the different analysis methods used by the authors

\begin{tabular}{|c|c|c|c|c|}
\hline \multicolumn{2}{|c|}{ Analysis Method } & Equipment & Materials & References \\
\hline \multirow{20}{*}{ Pyramid method } & $\begin{array}{l}\text { Heating / cooling at } 3 \\
{ }^{\circ} \mathrm{C} / \mathrm{min} \text { constant rate }\end{array}$ & Perkin Elmer DSC 7 & Lauric acid $(77.05 \mathrm{wt} \%)+$ palmitic acid $(22.95 \mathrm{wt} \%)$ & Zhang et al. [32] \\
\hline & \multirow{19}{*}{$\begin{array}{l}\text { Heating/cooling at } 5 \\
{ }^{\circ} \mathrm{C} / \mathrm{min} \text { constant rate }\end{array}$} & Setaram DSC 131 & Paraffin $(70 w t \%)+$ PP $(30 w t$ & Alkan et al. [30] \\
\hline & & Perkin Elmer Jade DSC & $\mathrm{C}_{17} \mathrm{H}_{36}$ & Sari et al. [31] \\
\hline & & Setaram DSC 131 & Capric acid $(55 \mathrm{wt} \%)+$ expanded perlite $(45 \mathrm{wt} \%)$ & Sari and Karaipekli [34] \\
\hline & & Perkin Elmer DSC 4 & Methyl palmitate & Nikolic et al. [39] \\
\hline & & Perkin Elmer DSC 4 & Methyl stearate & Nikolic et al. [39] \\
\hline & & Perkin Elmer Diamond DSC & Palmitic acid $(80 \mathrm{wt} \%)+$ expanded graphite $(20 \mathrm{wt} \%)$ & Sari and Karaipekli [41] \\
\hline & & Calorimeter & $\mathrm{NaCH}_{3} \mathrm{COO} \cdot 3 \mathrm{H}_{2} \mathrm{O}$ & Wada et al. [61] \\
\hline & & DSC & $\left(\mathrm{NH}_{4} \mathrm{Al}\left(\mathrm{SO}_{4}\right)_{2} \cdot 12 \mathrm{H}_{2} \mathrm{O}\right)(15 \%)+\left(\mathrm{NH}_{4} \mathrm{NO}_{3}\right)(85 \%)$ & Jotshi et al. [49] \\
\hline & & Setaram DSC 131 & Capric acid $(73.5 \mathrm{wt} \%)+$ myristic acid $(26.5 \mathrm{wt} \%)$ & Karaipekli et al. [54] \\
\hline & & Setaram DSC 131 & Capric acid $+(83 \mathrm{wt} \%)+$ stearic acid $(17 \mathrm{wt} \%)$ & Karaipekli et al. [35] \\
\hline & & DuPont 2000 DSC & Lauric acid $(66 \mathrm{wt} \%)+$ myristic acid $(34 \mathrm{wt} \%)$ & Sari [52] \\
\hline & & DuPont 2000 DSC & Lauric acid $(69 \mathrm{wt} \%)+$ palmitic acid $(31 \mathrm{wt} \%)$ & Sari et al. [51] \\
\hline & & DuPont 2000 DSC & Lauric acid $(75.5 \mathrm{wt} \%)+$ stearic acid $(24.5 \mathrm{wt} \%)$ & Sari et al. [51] \\
\hline & & Perkin Elmer DSC 4 & Methyl stearate $(86 \mathrm{wt} \%)+$ methyl palmitate $(14 \mathrm{wt} \%)$ & Nikolic et al. [39] \\
\hline & & Perkin Elmer DSC 4 & Methyl stearate $(91 \mathrm{wt} \%)+$ cetyl palmitate $(9 \mathrm{wt} \%)$ & Nikolic et al. [39] \\
\hline & & Perkin Elmer DSC 4 & Methyl stearate $(91 \mathrm{wt} \%)+$ cetyl stearate $(9 \mathrm{wt} \%)$ & Nikolic et al. [39] \\
\hline & & DuPont 2000 DSC & Myristic acid $(58 \mathrm{wt} \%)+$ palmitic acid $(42 \mathrm{wt} \%)$ & Sari et al. [51] \\
\hline & & DuPont 2000 DSC & Myristic acid $(64 \mathrm{wt} \%)+$ stearic acid $(36 \mathrm{wt} \%)$ & Sari et al. [52] \\
\hline & & Perkin Elmer Jade DSC & Myristic acid + glycerol & Sari et al. [55] \\
\hline
\end{tabular}




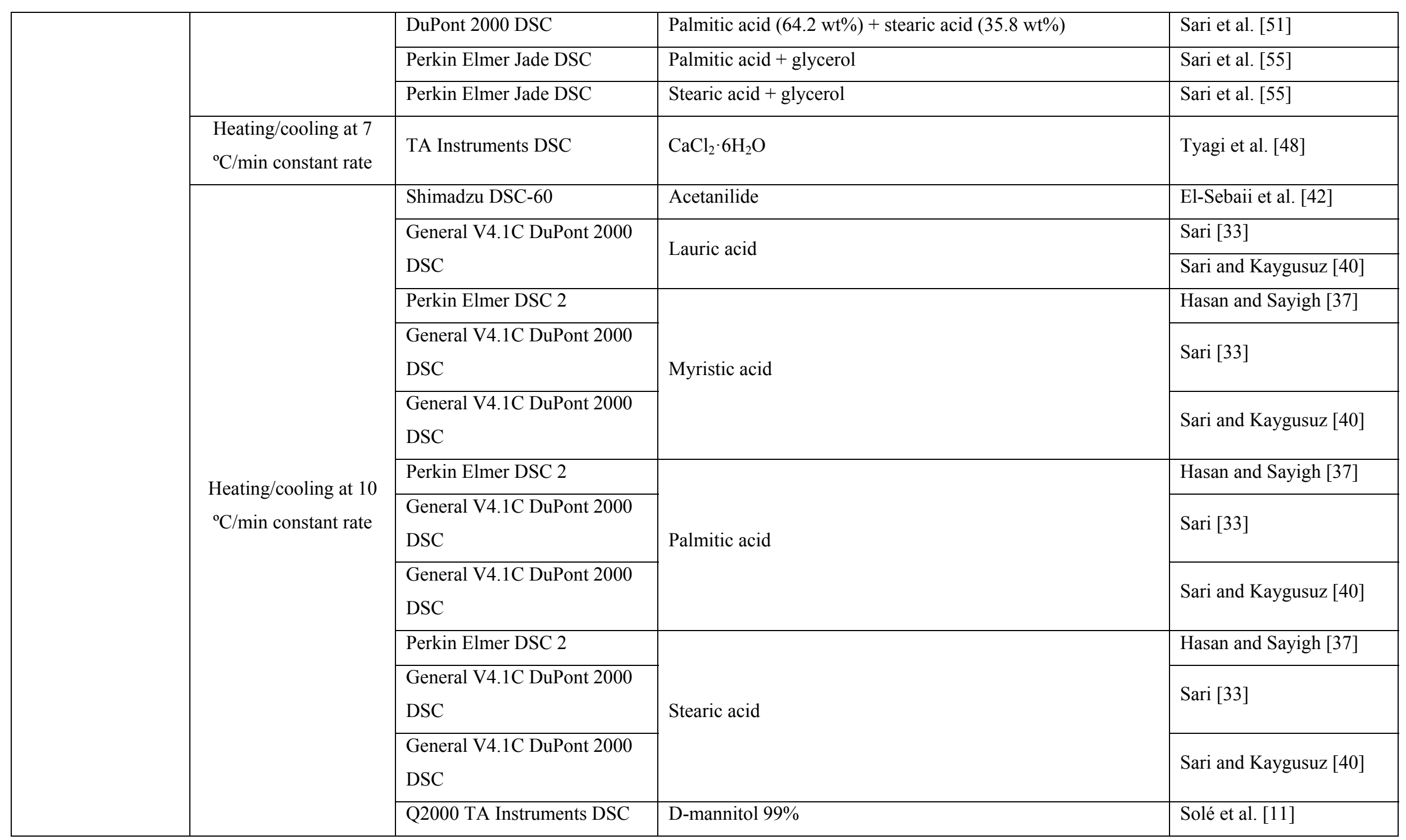




\begin{tabular}{|c|c|c|c|c|}
\hline & & Q2000 TA Instruments DSC & Myo-inositol 98\% & Solé et al. [11] \\
\hline & & Q2000 TA Instruments DSC & Galacticol 97\%, & Solé et al. [11] \\
\hline & & \multirow{2}{*}{ Shimadzu DSC-60 } & \multirow{2}{*}{$\mathrm{MgCl}_{2} \cdot 6 \mathrm{H}_{2} \mathrm{O}$} & El-Sebaii et al. [42] \\
\hline & & & & El-Sebaii et al. [58] \\
\hline & & Q10-V5.1-Build191 DSC & Al-34\%Mg-6\%Zn alloy & Sun et al. [57] \\
\hline & & Perkin Elmer Diamond DSC & Caprylic acid $(70 \mathrm{wt} \%)+1$-dodecanol (30 wt\%) & Zuo et al. [56] \\
\hline & $\begin{array}{l}\text { Non specified constant } \\
\text { rate }\end{array}$ & $\begin{array}{l}\text { Rheometric Scientific Ltd. } \\
\text { DSC }\end{array}$ & Urea & Sharma et al. [38] \\
\hline \multirow{5}{*}{ Dynamic method } & \multirow{5}{*}{ No specifications } & \multirow{5}{*}{$\begin{array}{l}\text { Rheometric Scientific Ltd. } \\
\text { DSC }\end{array}$} & Paraffin wax 53 & Sharma et al. [26] \\
\hline & & & Paraffin wax 53 & Sharma et al. [27] \\
\hline & & & Acetamide & Sharma et al. [26] \\
\hline & & & Acetamide & Sharma et al. [27] \\
\hline & & & Stearic acid & Sharma et al. [26] \\
\hline
\end{tabular}


Table 12. Materials classified by number of cycles range

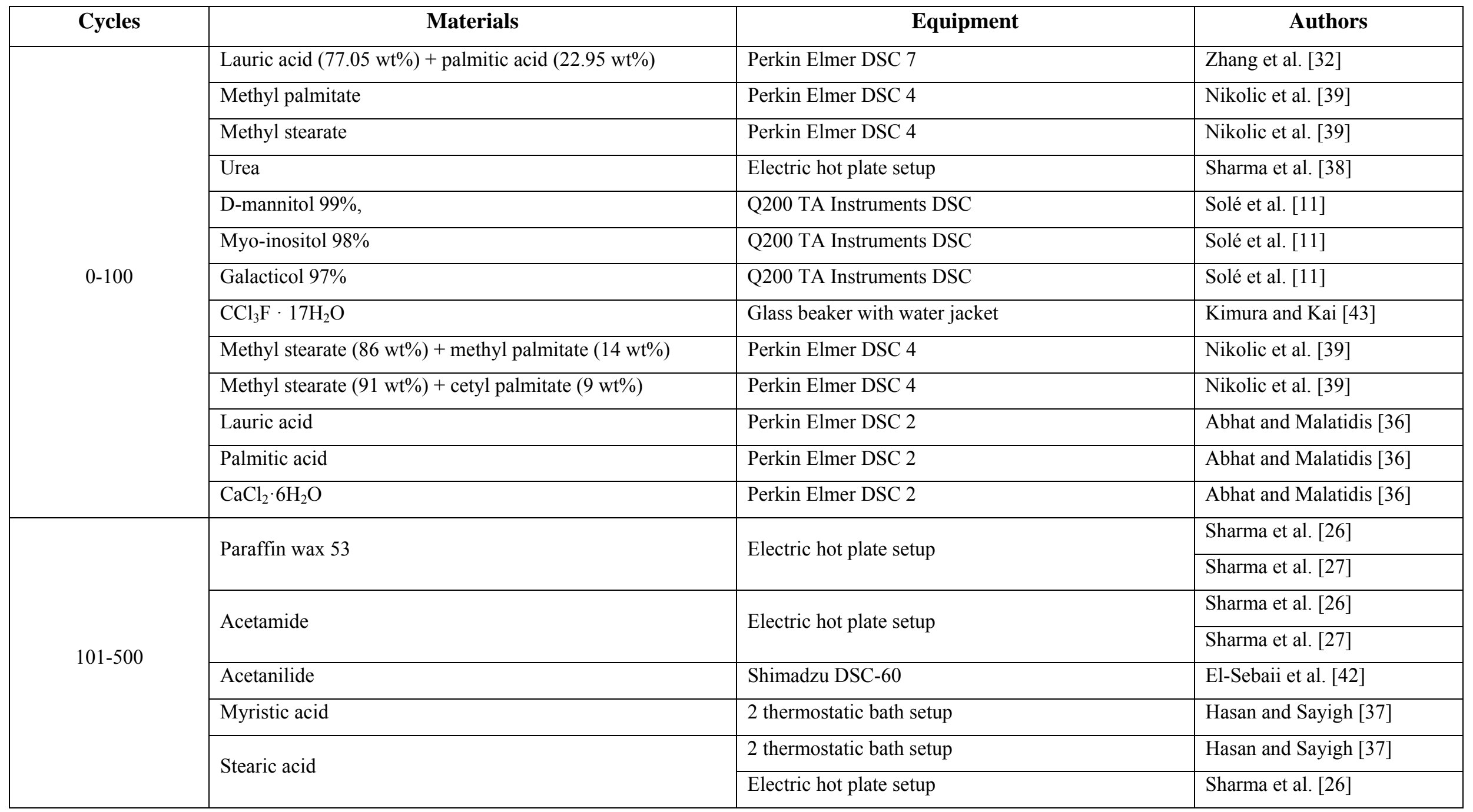




\begin{tabular}{|c|c|c|c|}
\hline & & & Sharma et al. [27] \\
\hline & Glauber's salt & Thermal cycling chamber & Marks [59] \\
\hline & $\mathrm{MgCl}_{2} \cdot 6 \mathrm{H}_{2} \mathrm{O}$ & Electric Oven & El-Sebaii et al. [42] \\
\hline & $\mathrm{NaCH}_{3} \mathrm{COO} \cdot 3 \mathrm{H}_{2} \mathrm{O}$ & Thermal bath & Wada et al. [61] \\
\hline & \multirow{2}{*}{ Capric acid $(65 \mathrm{~mol} \%)+$ lauric acid (35 mol\%) } & Thermostatic water bath setup & Dimaano and Escoto [50] \\
\hline & & Electric hot plate setup & Shilei et al. [53] \\
\hline & Caprylic acid $(70 \mathrm{wt} \%)+1$-dodecanol (30 wt $\%)$ & Thermostatic chamber setup & Zuo et al. [56] \\
\hline & Lauric acid $(75.5 \mathrm{wt} \%)+$ stearic acid $(24.5 \mathrm{wt} \%)$ & Thermostatic chamber setup & Sari et al. [51] \\
\hline & Myristic acid $(58 \mathrm{wt} \%)+$ palmitic acid $(42 \mathrm{wt} \%)$ & Thermostatic chamber setup & Sari et al. [51] \\
\hline & Palmitic acid $(64.2 \mathrm{wt} \%)+$ stearic acid $(35.8 \mathrm{wt} \%)$ & Thermostatic chamber setup & Sari et al. [51] \\
\hline \multirow{13}{*}{$501-1000$} & Paraffin $\left(\mathrm{C}_{22} \mathrm{H}_{44.1}\right)$ & Thermostatic bath setup & Hadjieva et al. [28] \\
\hline & Paraffin $\left(\mathrm{C}_{23} \mathrm{H}_{48.4}\right)$ & Thermostatic bath setup & Hadjieva et al. [28] \\
\hline & Paraffin wax 58-60 & Oven & Shukla et al. [29] \\
\hline & Paraffin wax 60-62 & Oven & Shukla et al. [29] \\
\hline & Erythritol & Oven & Shukla et al. [29] \\
\hline & Lauric acid & Thermostatic chamber setup & Sari and Kaygusuz [40] \\
\hline & Palmitic acid & Thermostatic chamber setup & Sari and Kaygusuz [40] \\
\hline & Stearic acid & Thermostatic chamber setup & Sari and Kaygusuz [40] \\
\hline & & Two tube water circulation setup & Kimura and Kai [60] \\
\hline & $\mathrm{CaCl}_{2} \cdot 6 \mathrm{H}_{2} \mathrm{O}$ & Water bath setup & Fellchenfeld et al. [44] \\
\hline & & TA Instruments DSC Q-100 & Tyagi et al. [48] \\
\hline & Al-34\%Mg-6\%Zn alloy & Thermostatic chamber setup & Sun et al. [57] \\
\hline & Myristic acid + glicerol & Thermostatic chamber setup & Sari et al. [55] \\
\hline
\end{tabular}




\begin{tabular}{|c|c|c|c|}
\hline & Palmitic acid + glicerol & Thermostatic chamber setup & Sari et al. [55] \\
\hline & Stearic acid + glicerol & Thermostatic chamber setup & Sari et al. [55] \\
\hline & $\mathrm{CaCl}_{2} \cdot 6 \mathrm{H}_{2} \mathrm{O}$ compounds & Perkin Elmer DSC 2 & Kimura and Kai [46] \\
\hline & $\mathrm{Mg}\left(\mathrm{NO}_{3}\right)_{2} \cdot 6 \mathrm{H}_{2} \mathrm{O}(93 \mathrm{wt} \%)+\mathrm{MgCl}_{2} \cdot 6 \mathrm{H}_{2} \mathrm{O}(7 \mathrm{wt} \%)$ & DSC & Nagano et al. [47] \\
\hline & Microencapsulated paraffin wax $53(0.1 \mathrm{~g}) /$ polyaniline $(0.9 \mathrm{~g})$ & Thermal box with heater and cooler setup & Silakhori et al. [62] \\
\hline & Microencapsulated paraffin wax $53(0.2 \mathrm{~g}) /$ polyaniline $(0.8 \mathrm{~g})$ & Thermal box with heater and cooler setup & Silakhori et al. [62] \\
\hline & Capric acid $(62 \mathrm{wt} \%)+$ tetradecanol $(38 w t \%)$ & Two thermostatic bath setup & Jingyu et al. [63] \\
\hline & Tetradodecanol (53.60 wt\%) + lauric acid (46.40 wt\%) & Two thermostatic bath setup & Jingyu et al. [63] \\
\hline & Tetradodecanol (71.84 wt\%) + myristic acid (28.16 wt\%) & Two thermostatic bath setup & Jingyu et al. [63] \\
\hline \multirow{14}{*}{$1001-3000$} & Paraffin wax 53 & Electric hot plate setup & Sharma et al. [27] \\
\hline & Acetamide & Electric hot plate setup & Sharma et al. [27] \\
\hline & Myristic acid, & Thermostatic bath setup & Sari [33] \\
\hline & Lauric acid & Thermostatic bath setup & Sari [33] \\
\hline & Palmitic acid & Thermostatic bath setup & Sari [33] \\
\hline & \multirow{2}{*}{ Stearic acid } & Thermostatic bath setup & Sari [33] \\
\hline & & Electric hot plate setup & Sharma et al. [27] \\
\hline & $\mathrm{MgCl}_{2} \cdot 6 \mathrm{H}_{2} \mathrm{O}$ & Heraeus D-6450 Electric Oven & El-Sebaii et al. [42] \\
\hline & $\left(\mathrm{NH}_{4} \mathrm{NO}_{3}\right)(85 \%)+\left(\mathrm{NH}_{4} \mathrm{Al}\left(\mathrm{SO}_{4}\right)_{2} \cdot 12 \mathrm{H}_{2} \mathrm{O}\right)(15 \%)$ & Calorimeter + thermal bath setup & Jotshi et al. [49] \\
\hline & Lauric acid $(66 \mathrm{wt} \%)+$ myristic acid $(34 \mathrm{wt} \%)$ & Thermostatic chamber setup & Sari [52] \\
\hline & Lauric acid $(69 w t \%)+$ palmitic acid $(31 \mathrm{wt} \%)$ & Thermostatic chamber setup & Sari [52] \\
\hline & Myristic acid $(64 w t \%)+$ stearic acid $(36 w t \%)$ & Thermostatic chamber setup & Sari [52] \\
\hline & Paraffin (70 wt\%) + Polypropylene (30wt\%) & Electric hot plate setup & Alkan et al. [30] \\
\hline & Palmitic acid $(80 \mathrm{wt} \%)+$ expanded graphite $(20 \mathrm{wt} \%)$ & Thermal cycler BIOER TC-25/H model & Sari and Karaipekli [41] \\
\hline
\end{tabular}




\begin{tabular}{|l|l|l|l|}
\hline \multirow{5}{*}{$3001-6000$} & $\mathrm{C}_{17} \mathrm{H}_{36}$ & Electric hot plate setup & Sari et al. [31] \\
\cline { 2 - 4 } & Capric acid $(55 \mathrm{wt} \%)+$ expanded perlite $(45 \mathrm{wt} \%)$ & Electric hot plate setup & Sari and Karaipekli [34] \\
\cline { 2 - 4 } & $\mathrm{CaCl}_{2} \cdot 6 \mathrm{H}_{2} \mathrm{O}$ & Thermostatic chamber & Porosini [45] \\
\cline { 2 - 4 } & Glauber's salt $\left(\mathrm{Na} 2 \mathrm{SO} 4 \cdot 10 \mathrm{H}_{2} \mathrm{O}\right)$ & Thermostatic chamber & Porosini [45] \\
\cline { 2 - 4 } & $\mathrm{Na}_{2} \mathrm{SO}_{4} \cdot 1 / 2 \mathrm{NaCl} \cdot 10 \mathrm{H}_{2} \mathrm{O}$ & Thermostatic chamber & Porosini [45] \\
\cline { 2 - 4 } & $\mathrm{NaOH} \cdot 3,5 \mathrm{H}_{2} \mathrm{O}$ & Thermostatic chamber & Porosini [45] \\
\cline { 2 - 4 } & Capric acid $(73.5 \mathrm{wt} \%)+$ myristic acid $(26.5 \mathrm{wt} \%)$ & Two water baths setup & Karaipekli et al. [54] \\
\cline { 2 - 4 } & Capric acid $+(83 \mathrm{wt} \%)+$ stearic acid $(17 \mathrm{wt} \%)$ & Electric hot plate setup & Karaipekli et al. [35] \\
\hline
\end{tabular}

